- Rapid ecosystem services assessment tools can provide key information to decision-makers, yet the specific context of African Biosphere Reserves makes a systematic, user-informed selection process essential.

- Based on a Delphi survey of future tool users, we propose a tool selection approach and a categorization of tools.

- The categorization of tools is based on requirements regarding data input, skills, outputs and types of ecosystem services addressed. 


\title{
Ecosystem services assessment tools for African Biosphere Reserves: a review and user- informed classification
}

\author{
Hugé, J., Rochette, A.J., de Béthune, S., Parra Paitan C.C., Vanderhaegen, K., Vandervelden, T., Van Passel, \\ S., Vanhove M.P.M., Verbist, B., Verheyen, D., Waas, T., Janssens de Bisthoven, L.
}

\begin{abstract}
While the concept of ecosystem services which links biodiversity to human wellbeing, is by now well-known, its translation into actual management decisions is still uneven. African Biosphere Reserves, which are to be living labs for sustainable development, embody the idea of synergies between people and nature. Gaining knowledge about the provision, the use and the trends of ecosystem services in these reserves is essential to ensure their global change-proof management. The diversity of rapidly evolving ecosystem services assessment tools requires a systematic and informed selection, in order to ensure that prospective tool users select the most adequate tool, aligned to their needs and context. Based on a Delphi survey of future tool users, and on a review of ecosystem services assessment tools, we propose guidance to users to select the most suited tool based on the context of African Biosphere Reserves, and on tool requirements regarding data input, necessary skills, outputs and types of ecosystem services addressed. The use of the a Delphi survey and the focus on African Biosphere Reserves are new elements that contribute to the theory and practice of ecosystem services assessment.
\end{abstract}

Keywords: ecosystem services, assessment tools, Biosphere Reserves, Africa, Delphi;

\section{Introduction}

Biodiversity is under threat at global and local level. Its continuous decline threatens human wellbeing directly and indirectly, as human systems and biodiversity-based natural systems are closely intertwined. The loss of biodiversity alters the functioning of ecosystems and decreases their ability to provide society with essential goods and services (Cardinale et al., 2012; Costanza et al., 2017). The diversity of services provided by ecosystems includes provisioning services such as freshwater and food, regulating services such as air and water purification and climate regulation, supporting services such as nutrient cycling, and cultural services reflecting the deeply embedded relations between human beings and nature (Mukherjee et al., 2014; Chan et al., 2016; IPBES, 2019). In this manuscript, we follow the four-categories classification of IPBES (2019), yet other classifications exist (van Oudenhoven et al., 2018). While ecosystem services are by now wellknown and well analysed (Costanza et al., 2017) as the 2005 Millennium Ecosystem Assessment and the recent work of the Intergovernmental Science-Policy Platform on Biodiversity and Ecosystem Services (IPBES) show, these services are under threat by ongoing unsustainable human development crossing the systemic boundaries representing the so-called 'safe operating space for humanity' (Steffen et al., 2015). The recent emergence of the 'nature's contributions to people'-idea in the constantly evolving concept of ecosystem services, fosters a more inclusive definition in which indigenous knowledge is explicitly considered (Diaz et al., 2018). The boom of ecosystem services research, applications and policies has led to high expectations among scientists, policymakers and natural resources managers regarding possible quick wins that could start turning the tide of biodiversity loss, while simultaneously enhancing e.g. carbon sequestration and delivery of 
watershed functions. However, moving from scientific knowledge and societal awareness about ecosystem services to effective real-world decision-making and impact remains challenging. Notwithstanding some success stories, ecosystem services are currently still inadequately acknowledged in decision-making processes (Ruckelshaus et al., 2015).

The wellbeing of people is directly dependent on ecosystem services (Suich et al., 2015) and access to the benefits provided by a steady flow of the ecosystem services contributes to poverty alleviation (Fisher et al., 2014). The challenge of biodiversity loss is particularly acute in developing countries, where economies and a large part of their population depends on goods and services provided by local ecosystems (IPBES, 2018). These countries, often rich with and highly dependent on natural resources, would benefit from the inclusion of ecosystem services in their policy-making processes. Although their economies and a large share of their population is directly dependent on goods and services provided by local ecosystems (IPBES, 2018), until now, these are often not managed sustainably. Africa in particular, has a high proportion of Least Developed Countries (UN CDP, 2018), contains multiple biodiversity hotspots (Myers et al., 2000) and shows a particularly high direct dependency on ecosystem services (e.g. 62 percent of its rural population depends directly of ecosystem services for its survival (IPBES, 2018)). Moreover, the continent is expected to suffer an ever-increasing decline in biodiversity, in part due to a rapidly expanding population as the continent's population is expected to double by 2050 , reaching 1.25 billion people (UN, 2019). The value of Africa's biodiversity for human well-being is still vastly under-researched (IPBES, 2018).

The linkages between the conservation of biodiversity which forms the basis of the generation of ecosystem services and human development, lies at the roots of UNESCO's Man and Biosphere (MAB) programme (Cuong et al., 2017). The programme finds its spatial expression in a global network of Biosphere Reserves (or MAB Reserves). These reserves must meet a minimal set of criteria in order to be proposed by national authorities and subsequently be designated by UNESCO. The sites are widely recognized as being locations where the sustainable development idea, which gained new momentum following the adoption of the Sustainable Development Goals (SDGs), can be implemented (Pool-Stanvliet et al., 2018). This network of sites also provides an opportunity to realize and fine-tune the 'ecosystems approach' to natural resource management, which fosters a strategy "for the integrated management of land, water and living resources that promotes conservation and sustainable use in an equitable way" (CBD, 2004).

Biosphere Reserves entail a mosaic of ecological (sub-)systems that typically provide a diverse set of ecosystem services and exhibit different degrees of vulnerability, and hence require a differential and adaptable management. They are typically divided into a protected core area, a buffer zone and a transition area (Pool-Stanvliet et al., 2018). This zonation allows for differential use of ecosystem services and for a range of management regimes within each Biosphere Reserve. Managers hence need to identify the ecosystem services delivered by the Biosphere Reserve and need to ensure the long-term provision of these services. Together with the additional income generated by carefully designed Payments for Ecosystem Services (PES) schemes, Biosphere Reserves can continue to improve the livelihoods of the millions of people living in their transition zones and beyond (UNESCO, 2016).

A better knowledge and integration of ecosystem services is a key priority for African Biosphere Reserves, as these reserves are facing high anthropogenic pressures. Common causes are the rapid population growth, its strong dependence on natural resources for its livelihoods, weak institutions and competing stakeholder interests in challenging governance conditions (German Federal Agency of Nature Conservation, 2011). Insight in the state and flux of ecosystem services and their use, and in the risks that ecosystem services are facing, is key for sustainable management (Maron 
et al., 2017). An assessment of the social and economic value of ecosystem services can provide important leverage to safeguard and manage Biosphere Reserves and their ecosystem services in a plural way, acknowledging the interests of a wide range of stakeholders. As an example of current threats to well-known and globally recognized biodiversity hotspots in Africa, the recent threats emanating from oil exploration in the Virunga National Park (Democratic Republic of the Congo) and the adjacent Queen Elizabeth Biosphere Reserve (Uganda) should be kept in mind. The economic value of the ecosystem services provided by the intact, un-exploited Virunga National Park, as compiled by WWF \& Dalberg (2013) fed the international pressure which ultimately convinced the Congolese government to opt for long-term conservation benefits instead of shortterm oil profits.

To ensure that ecosystem services contribute to improved decision-making, the assessment of these services -and their contributions to human wellbeing needs to become systematic, quantifiable, robust and credible (Bagstad et al., 2013). Solid methods to assess and map ecosystem services exist, but remain insufficiently known, used and communicated (Maes et al., 2013; Martinez-Harms et al., 2016; Ruckelshaus et al., 2015). Many decision-support tools have been developed in recent years, yet their applicability and user-friendliness are often context-, site- and user-specific. Moreover, their application is often limited due to high demands of data, skills, time and resources. In order to structure and understand the diversity of these tools, some authors performed reviews attempting to classify these methods and analyse their trade-offs. Bagstad et al. (2013) evaluated ecosystem services assessment tools based on their suitability to be mainstreamed in environmental decision-making processes in the most resource-efficient way. Pandeya et al. (2016) reviewed tools that contribute to better policy making and are locally applicable in data-scarce areas. Grêt-Regamey et al. (2017) reviewed tools that have been operationalized into decision-support for a range of sectors such as water, soil, forest, agriculture and transport; while IUCN (2018) reviewed tools to model and value ecosystem services in among others World Heritage Sites and Key Biodiversity Areas. Despite these valuable efforts, a review of widely applicable, rapid and affordable tools to assess multiple ecosystem services in the specific context of African Biosphere Reserves, building on the expectations of the prospective users of such tools, was still lacking. In this study, we identify the expectations of prospective tool users, review existing rapid ecosystem services assessment tools based on an integration of these user-generated criteria and criteria from the literature, and subsequently provide users with guidance on ecosystem services assessment tool selection.

In order to ensure that managers of African Biosphere Reserves and other stakeholders gain rapid and reliable access to the ecosystem services assessment tools that are best suited to their demands, their capacities and the available data and resources, this study aims to:

- Provide insight into the evolving landscape of ecosystem services assessment tools and their applicability in the context of African Biosphere Reserves;

- Identify the perspective of prospective users of ecosystem services assessment tools (e.g. Biosphere Reserve managers) on management challenges and preferences regarding tool format and objectives;

- Evaluate the characteristics of ecosystem services assessment tools to facilitate an informed selection process when choosing which tool to apply;

- Critically reflect on the design and the use of current and future ecosystem services assessment tools in African Biosphere Reserves. 


\section{Methodology}

\subsection{Selecting ecosystem services assessment tools for African Biosphere Reserves: a stepwise approach}

The diversity of ecosystem services assessment tools (see e.g. Bagstad et al., 2013; Grêt-Regamey et al., 2017; IUCN, 2018) can make it difficult for prospective tool users to see the wood for the trees. We opted for a three-step approach to identify the tools that may be suitable for African Biosphere Reserves.

Step 1: Selection of ecosystem services assessment tools based on a review of existing tools, on the scientific literature and on the specific context of African Biosphere Reserves. This selection was based on the 'initial selection criteria'.

Step 2: Identification of 'user-generated characteristics' to perform a detailed assessment of ecosystem services assessment tools;

Step 3: Classification of selected tools.

\subsection{Step 1: Selection of a range of ecosystem services assessment tools}

An initial screening of ecosystem services assessment tools, frameworks, guidelines and methods (from now on referred as 'tools') was carried out based on the review of the literature in specialized scientific journals (including: Ecosystem Services, Ecological Economics, Ecological Indicators, Ecological Modelling, and the Journal of Environmental Management) and in the scientific search engines Web of Science and Google Scholar for the following keywords: ecosystem services assessment, ecosystem services tool, ecosystem services toolkit, ecosystem services framework, ecosystem services guideline(s) and ecosystem services assessment method. Additional tools were identified from specialized databases built by the Ecosystem Knowledge Network. (https://ecosystemsknowledge.net/), the Ecosystem Services Partnership (https://www.es-partnership.org/) and the ValuES method navigator (http://www.aboutvalues.net/method navigator/). Key sources for this step include: Bagstad et al. (2013), Grêt-Regamey et al. (2017), Oosterbroek et al. (2016), Pandeya et al. (2016), Peh et al. (2013). Only tools that fulfilled the following set of 'initial selection criteria' were selected for Step 2:

- Generalizable (i.e. applicable across a variety of social-ecological settings, while allowing to take into account different local specificities), to account for the diversity of African Biosphere Reserves;

- Applicable at the landscape scale (i.e. going beyond application on small patches only, allowing to include large zones with different management regimes and/or intensity), as African Biosphere Reserves typically encompass zones (core area, buffer zone, transition area) with different management rules;

- Applicable independently (i.e. without a priori requiring external expertise); as there is typically a lack of availability of ecosystem services expertise in African Biosphere Reserves;

- Affordable (i.e. without requiring a priori financial investment); as African Biosphere Reserves typically lack sustainable funding;

- Able to assess multiple ecosystem services (i.e. not focusing on only one category of ecosystem services (e.g. not only carbon sequestration, or only water)), as African Biosphere Reserves encompass a wide range of ecosystem services; 
- Rapid (i.e. requiring less than a year to apply the tool), as African Biosphere Reserve staff are often burdened by excessive workload and as management decisions often need to be made on relatively short time scales.

The initial selection criteria were based on the objectives of the study (identifying rapid and accessible tools within the context of African Biosphere Reserves). The specificities of the African Biosphere Reserves-context were based on a document of the German Federal Agency of Nature Conservation (2011). The initial selection criteria were then complemented with a range of tool characteristics that reflect the preferences of potential tool users. These characteristics were compiled by way of a Delphi exercise (see Section 2.3).

\subsection{Step 2: Identification of user preferences regarding ecosystem services assessment tools}

Despite the increasing awareness of including stakeholder preferences into decision-making, until now, reviews focusing on ecosystem services assessment tools have typically failed to systematically acknowledge the perspective of prospective tool users. In order to gather the perspectives and expectations of the prospective users of ecosystem services assessment tools in African Biosphere Reserves, we used the Delphi technique. The Delphi technique is a structured, anonymous and iterative survey, and typically aims to addressing complex issues that require inputs from different disciplines and backgrounds (Mukherjee et al., 2015). The Delphi participants remain mutually anonymous (no participant knows what any other participant is responding), which contributes to address a range of social pressures that can negatively affect group-based approaches (biases such as groupthink, halo effects, egocentrism, and dominance are reduced - as there is no face-to-face interaction among participants) (Mukherjee et al., 2015). During the successive rounds of the iterative Delphi survey, participants tend to move towards consensus on some issues, as they are progressively exposed to the opinions of their peers (Mukherjee et al., 2015). In our study, we set the level of consensus at $>50 \%$, meaning that a tool's characteristic is accepted (deemed relevant for an ecosystem services assessment tool) if at least $50 \%$ of the respondents selected the characteristic after round 2 (which is in line with Von der Gracht (2012) and Mukherjee et al., (2015)).

For this study, all Delphi participants were members of the African Network of Biosphere Reserves (AfriMAB), who are all involved with the strategic and/or day-to-day management of African Biosphere Reserves. All attendants of the $5^{\text {th }}$ General Assembly of AfriMAB, held in Ibadan, Nigeria, in September 2017, were given the opportunity to participate in the Delphi survey. We conducted a two-round Delphi survey, that could be answered online using Google Forms, or completed on paper forms. Each Delphi round consisted of two main sections: $i$. the management challenges faced by African Biosphere Reserve managers; $i i$. the desired characteristics of ecosystem services assessment tools (reflecting users' expectations of these tools). The two rounds of the online survey were completed individually and anonymously by the respondents in September 2017. Twenty-four respondents participated in the first Delphi round, and twenty-two participants took part in the second round, which is in line with the average number of respondents in Delphi studies as reported by Mukherjee et al. (2015) and Hugé et al. (2018). The profile of the respondents is described in the Results section. 


\subsection{Step 3: Classification of selected tools}

In step 3, ecosystem services assessment tools are classified based on the required inputs, the outputs, the skills required to apply the tool and the ecosystem services that are considered by the tool. This classification is visualized by Venn-diagrams (Figures 2-5), and all selected tools are briefly described in Table 4.

\section{Results}

\subsection{Results of Step 1: from a longlist to a shortlist of ecosystem services assessment tools}

Appendix 1 provides an overview of the 51 ecosystem services assessment tools that were selected during the initial screening, using the initial selection criteria (Step 1). This longlist of tools was then reduced to 17 tools, following the steps outlined in Sections 2.1 and 2.2, using the usergenerated selection criteria. These 17 selected tools (the 'shortlist') are evaluated and classified in Section 3.3 below.

\subsection{Results of Step 2: user expectations regarding ecosystem services assessment tools}

\subsubsection{Profile of the Delphi respondents}

We present the profiles of the respondents of the second round $(n=22)$, as these respondents completed the full Delphi process (in line with Mukherjee et al., 2014). Figure 1 gives the profile of the actual Delphi respondents and the profile of all the participants to the 2017 AfriMAB General Assembly (which hence represents the population from which the Delphi respondents originate).

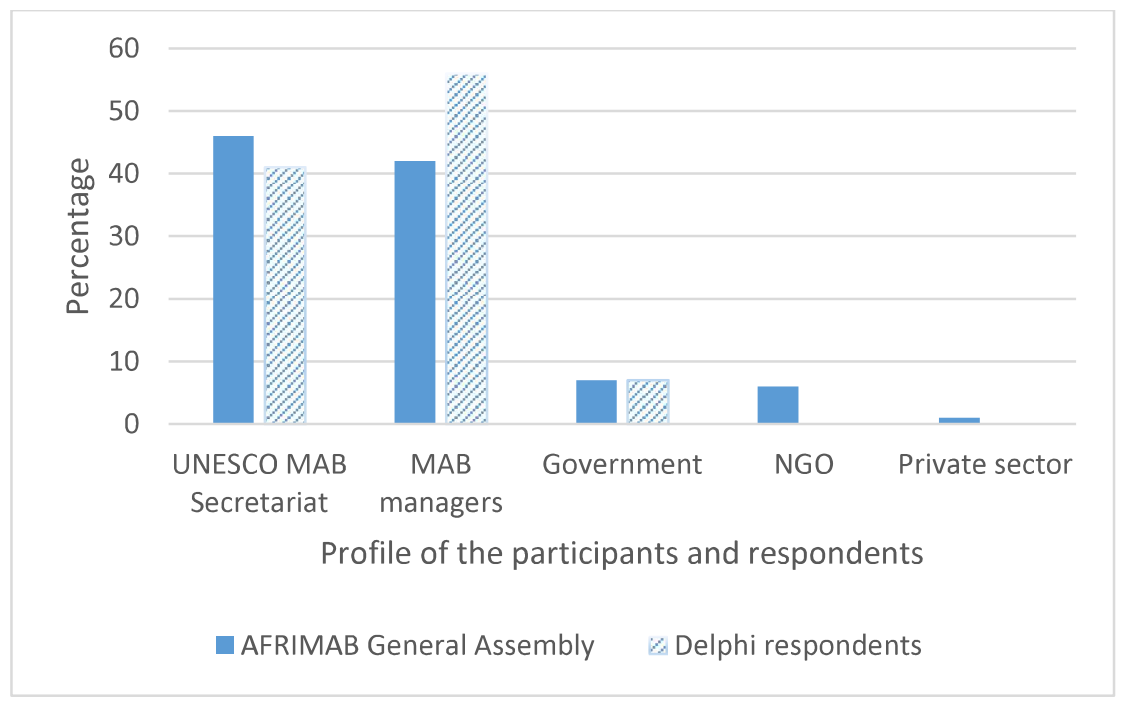

Figure 1: Profile of the Delphi respondents and the participants to the 2017 AfriMAB General Assembly (in \%) 


\subsubsection{Main management challenges faced in African Biosphere Reserves}

Table 1 presents the main management challenges according to the Delphi respondents

Table 1: Main management challenges in African Biosphere Reserves according to the respondents. Only challenges scoring over $>50 \%$ consensus are mentioned with the percentage indicating the share of respondents that selected this challenge. The trends in scores between round 1 and round 2 are indicated.

\begin{tabular}{|l|c|c|c|}
\hline & Consensus level & Score variance & $\begin{array}{c}\text { Trends in scores } \\
\text { between rounds }(\uparrow \\
\text { indicates increase, } \downarrow \\
\text { indicates decrease) }\end{array}$ \\
\hline Inadequate financial resources & $90 \%$ & $15 \%$ & $\uparrow$ \\
\hline Pressure from human activities & $70 \%$ & $20 \%$ & $\uparrow$ \\
\hline $\begin{array}{l}\text { Limited capacity (e.g. human } \\
\text { resources) }\end{array}$ & $55 \%$ & $15 \%$ & $\uparrow$ \\
\hline $\begin{array}{l}\text { Unavailability of data to support } \\
\text { management }\end{array}$ & $55 \%$ & $20 \%$ & \\
\hline
\end{tabular}

\subsubsection{Desired characteristics of ideal-typical ecosystem services assessment tools}

Table 2 outlines the desired characteristics of an ideal-typical ecosystem services assessment tool, according to the Delphi respondents. Criteria to evaluate ecosystem services assessment tools can be drawn from this set of user-generated desirable characteristics. These criteria are synthesized in Section 3.3.

Table 2: Results of the Delphi (after 2 rounds) regarding the desired characteristics of ecosystem services assessment tools. Only characteristics with scores showing $>50 \%$ consensus are presented. (ES stands for ecosystem services)

\begin{tabular}{|c|c|c|c|c|}
\hline \multicolumn{2}{|c|}{ Tool characteristics } & $\begin{array}{l}\text { Consensus } \\
\text { level }\end{array}$ & $\begin{array}{l}\text { Score } \\
\text { variance }\end{array}$ & $\begin{array}{l}\text { Trend in scores } \\
\text { between rounds } \\
\text { ( } \uparrow \text { indicates increase, }= \\
\text { indicates stable trend, } \\
\text { indicates decrease) }\end{array}$ \\
\hline \multirow{3}{*}{ Inputs } & Maps & $78 \%$ & $15 \%$ & $\downarrow$ \\
\hline & Quantitative input & $83 \%$ & $5 \%$ & $=$ \\
\hline & Qualitative input & $61 \%$ & $5 \%$ & $\downarrow$ \\
\hline \multirow{3}{*}{ Skills required } & $\begin{array}{l}\text { Low expertise } \\
\text { requirements to be applied }\end{array}$ & $55 \%$ & $20 \%$ & $\uparrow$ \\
\hline & $\begin{array}{l}\text { Hiring someone to apply } \\
\text { ES assessment tools }\end{array}$ & $84 \%$ & & $\uparrow$ \\
\hline & $\begin{array}{l}\text { Fieldwork technically } \\
\text { demanding }\end{array}$ & $56 \%$ & $20 \%$ & $\uparrow$ \\
\hline
\end{tabular}




\begin{tabular}{|c|c|c|c|c|}
\hline & Fieldwork expensive & $67 \%$ & $10 \%$ & $\uparrow$ \\
\hline \multirow{3}{*}{ Outputs } & Quantitative output & $53 \%$ & $15 \%$ & $\uparrow$ \\
\hline & Economic valuation & $58 \%$ & $5 \%$ & $\uparrow$ \\
\hline & $\begin{array}{l}\text { Provide results that are } \\
\text { easy to communicate }\end{array}$ & $55 \%$ & $5 \%$ & $\uparrow \uparrow$ \\
\hline $\begin{array}{l}\text { Ecosystem services } \\
\text { addressed }\end{array}$ & $\begin{array}{l}\text { Ability to assess multiple } \\
\text { types of ES }\end{array}$ & $60 \%$ & $10 \%$ & $\downarrow$ \\
\hline \multirow{4}{*}{ Purpose } & $\begin{array}{l}\text { Environmental awareness } \\
\text { raising \& education }\end{array}$ & $70 \%$ & $10 \%$ & $\downarrow$ \\
\hline & $\begin{array}{l}\text { Scoping \& description of } \\
\text { provided ES }\end{array}$ & $65 \%$ & $10 \%$ & $\bar{\uparrow}$ \\
\hline & $\begin{array}{c}\text { Supporting ES monitoring } \\
\& \text { evaluation }\end{array}$ & $65 \%$ & $25 \%$ & $\uparrow$ \\
\hline & $\begin{array}{l}\text { Identifying livelihood, } \\
\text { development \& investment } \\
\text { opportunities }\end{array}$ & $55 \%$ & $25 \%$ & $\downarrow$ \\
\hline
\end{tabular}

\subsubsection{Fine-tuning the user-generated tool characteristics}

In order to fine-tune the desired characteristics expressed by the -future- tool users in Table 2, we propose sub-categories for the user-generated characteristics, and we add an estimate of the time required to apply the tool. The characteristics and their sub-categories are based on the Delphi (see Table 2) and complemented by sub-categories from the existing literature (incl. Peh et al., 2013; Grêt-Regamey et al., 2017; Pagella \& Sinclair, 2014; Turner et al., 2016; Villa et al., 2014).

Table 3: Synthesis table outlining characteristics of ecosystem services assessment tools, based on the finetuning of user-generated preferences

\begin{tabular}{|c|c|}
\hline Tool characteristics & Categories (multiple possibilities per tool) \\
\hline Inputs & $\begin{array}{l}\text { - Spatial data (maps, GIS data) } \\
\text { - Stakeholder-based input } \\
\text { - Data from field sampling (own site-specific data) - primary sources } \\
\text { - Available data - secondary sources }\end{array}$ \\
\hline Skills required & $\begin{array}{l}\text { - } \text { GIS software \& skills } \\
\text { - Skills in field ecology } \\
\text { - Skills in stakeholder's involvement/ participatory processes }\end{array}$ \\
\hline Outputs & $\begin{array}{l}\text { - Spatial data } \\
\text { - Qualitative outputs } \\
\text { - Quantitative outputs } \\
\text { - Economic valuation }\end{array}$ \\
\hline Ecosystem services addressed & - Provisioning \\
\hline
\end{tabular}




\subsection{Results of Step 3: Classification of the selected ecosystem services assessment tools}

Table 4 describes all ecosystem services assessment tools that meet the initial selection criteria outlined in Step 1 (Section 2.2), and describes these tools using the user-generated key tool characteristics outlined in Table 3 (Section 3.2). 


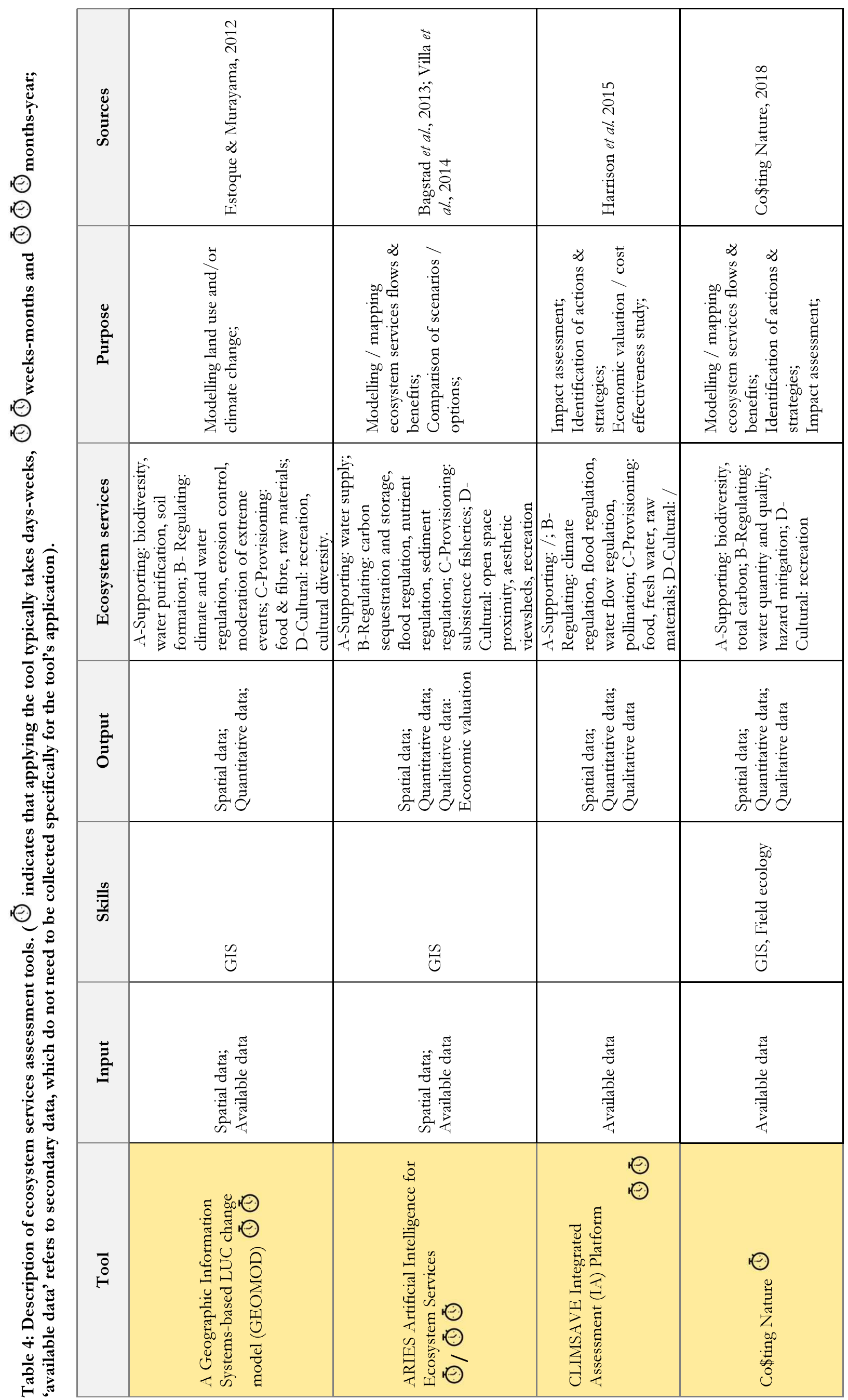

욱 


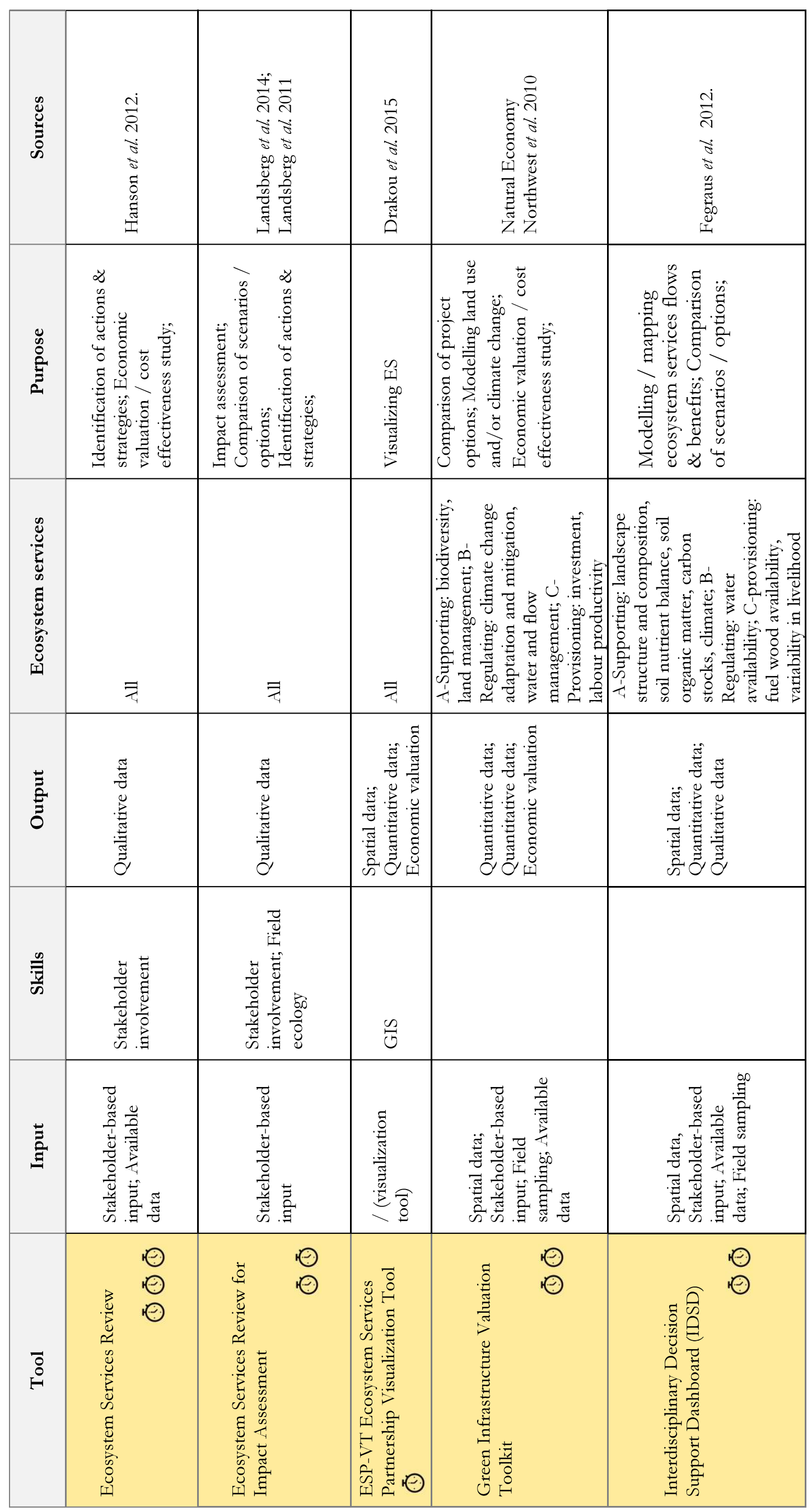




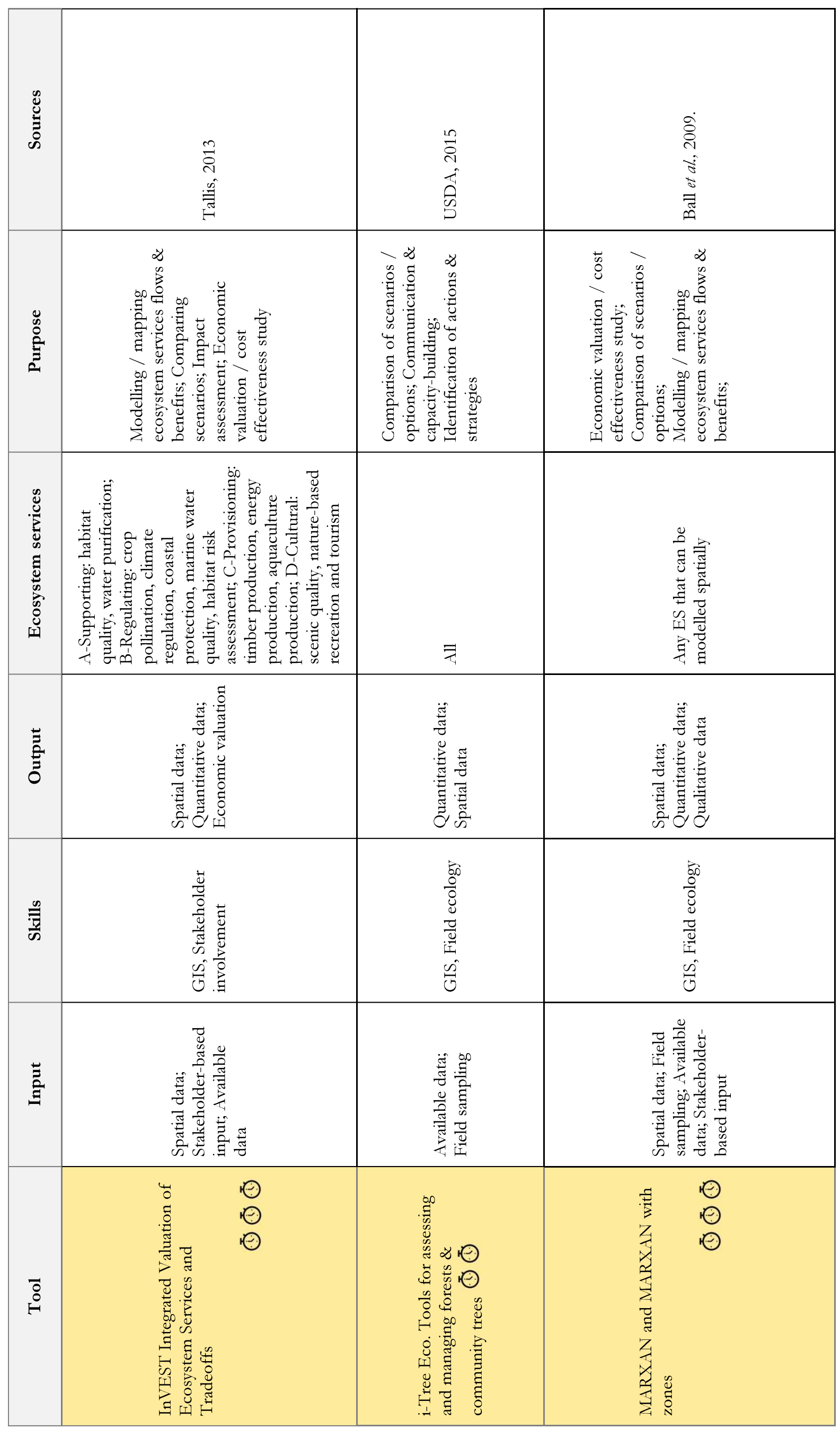

ㄱำ 


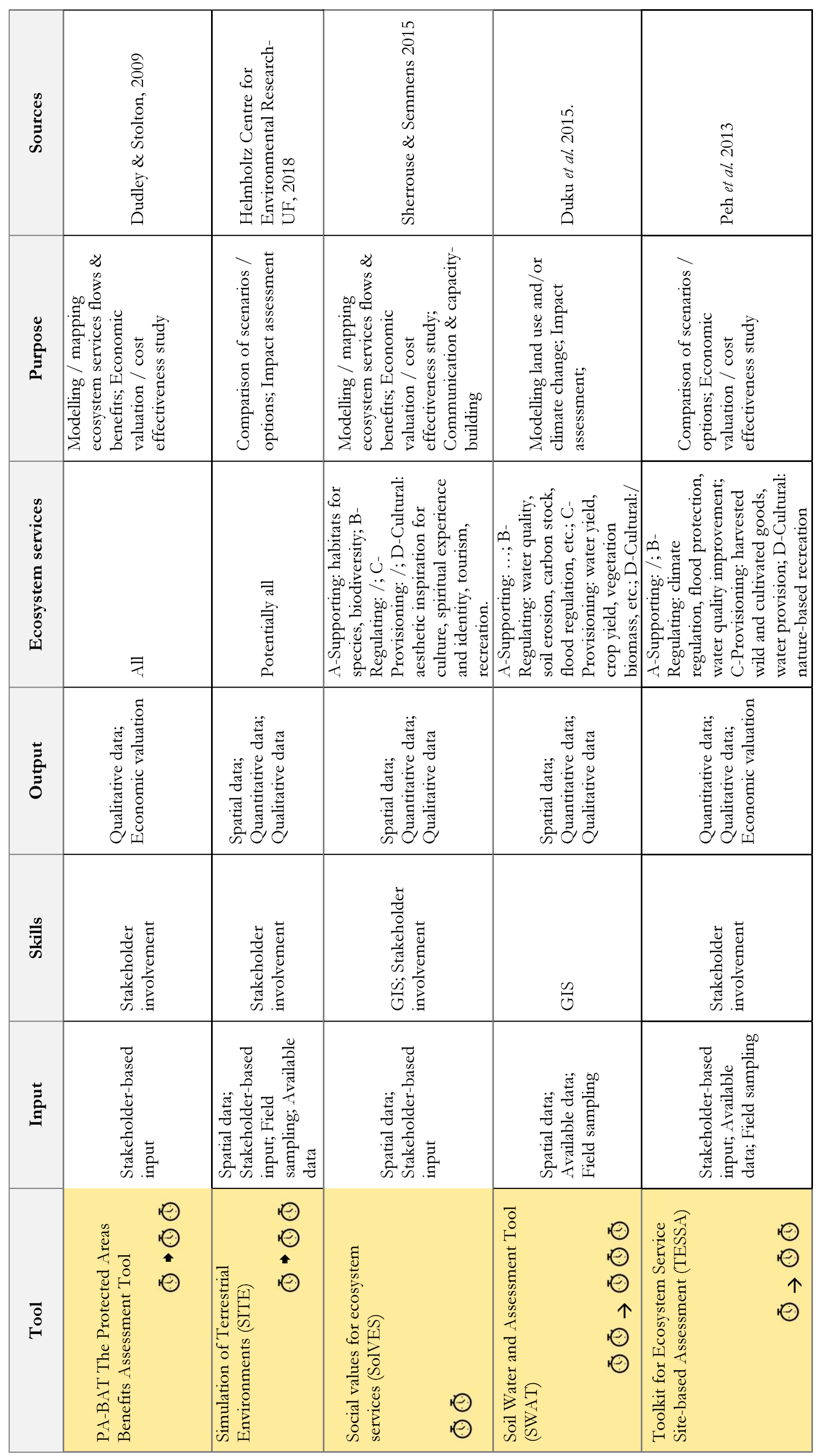




\subsection{Visual representation of the ecosystem services assessment tools}

While Table 4 provides a detailed schematic description of every ecosystem services assessment tool, Figure 2-5 provide a visualization of the inputs, outputs, required skills and addressed ecosystem services for each tool (the 'components' of each lens are in line with Table 3). The full names of the tools can be found in Table 4. This visual representation allows prospective tool users to quickly select which tool suits their needs and capacities best. Moreover, it allows to select tools based on different perspectives (e.g. based on available input data, on desired outputs etc.). As can be seen in the Figures, some tools require a combination of data types, and multiple skills, while other tools can be applied with a more limited range of skills and/or data. Future tool users can select the most adequate tool according to their expectations, data availabilities and available capacity. The tools are placed in their respective Venn-diagrams based on the descriptions and reports of applications of the tools. Figures 2-5 are simplified representations of some key characteristics of the tools (e.g. some quantitative output tools can allow for -some- economic valuation too), and/or tools can of course be combined.

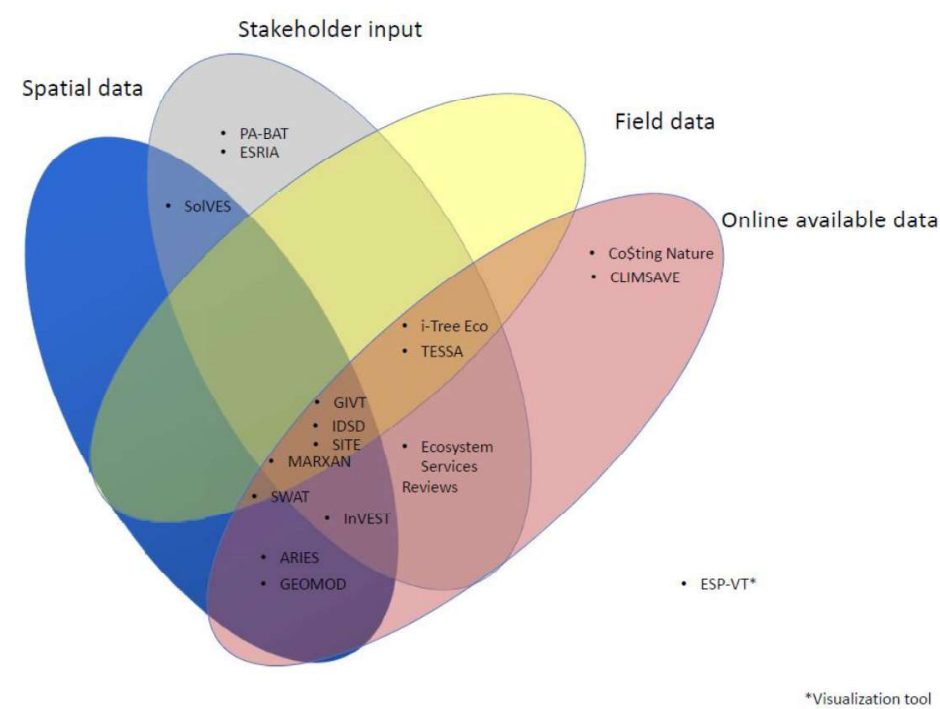

only

Figure 2: Overview of ecosystem services assessment tools based on required input data (online available data refers to secondary data, which have already been collected prior to the application of the tool) 


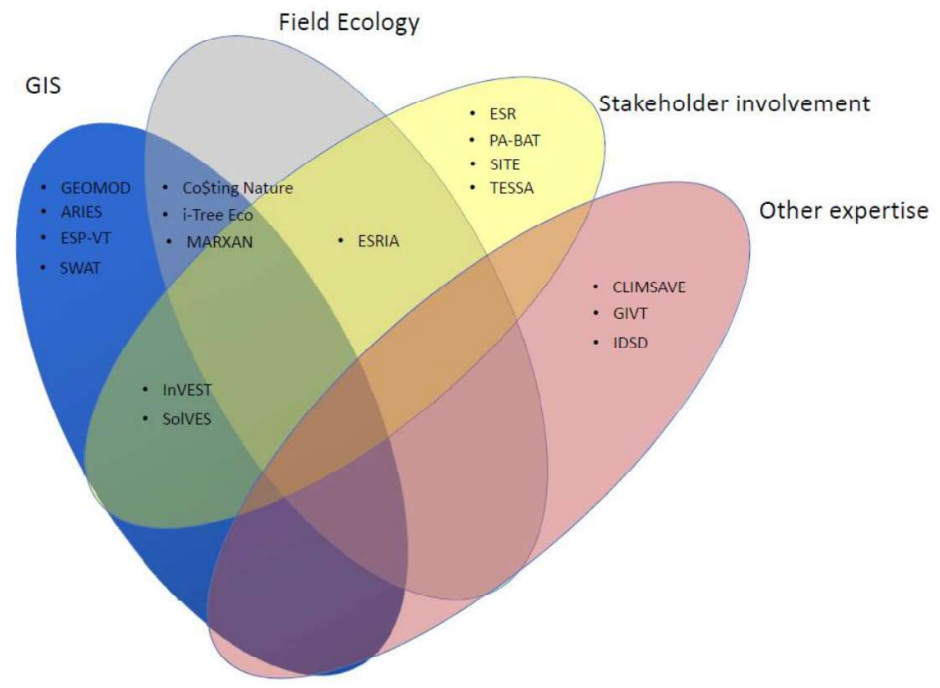

Figure 3: Overview of ecosystem services assessment tools based on required skills

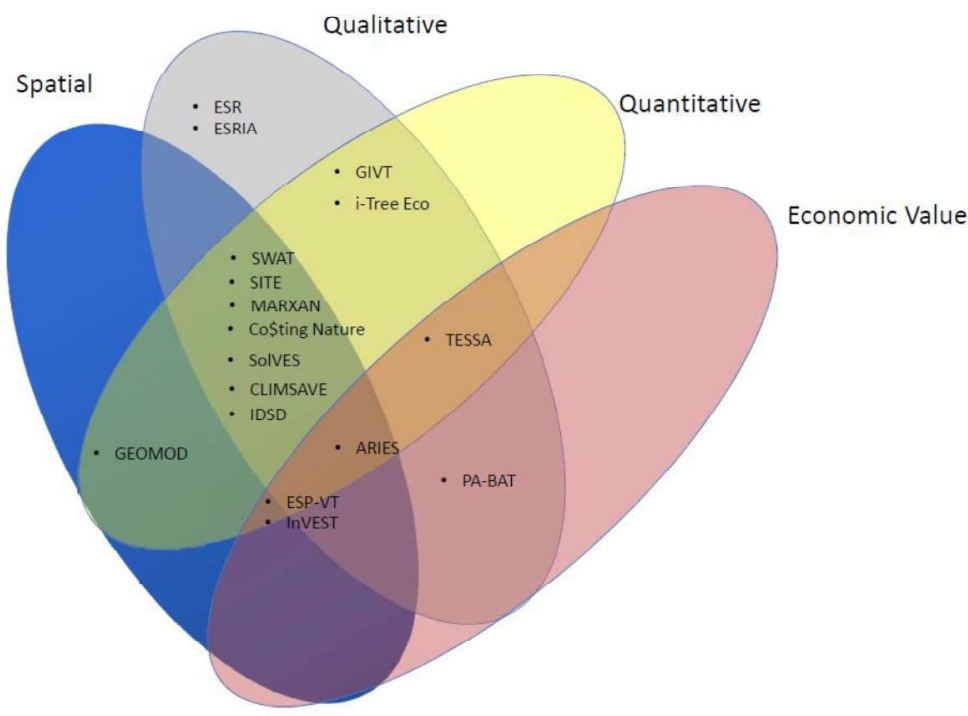

Figure 4: Overview of ecosystem services assessment tools based on generated output data 


\section{Discussion}

\subsection{The methodological challenge of selecting suitable ecosystem services assessment tools}

The potential impact one can have on decision-making by adopting and translating the concept of ecosystem services has triggered high expectations among scientists and managers since the concept was popularized in 2005. This has led to the development of a wide range of tools that have as stated aims the translation, visualization and 'easy' communication of the inherently complex processes that drive the provision, use and management of ecosystem services. Faced with real-world constraints such as limited time, limited financial resources and limited capacity, scientists, reserve managers and decision-makers constantly need to make trade-offs regarding which tool to use to assess and map ecosystem services. While other authors have proposed categorizations and criteria to select the most appropriate ecosystem services assessment tools (e.g. Bagstad et al., 2013; Pandeya et al., 2016, Grêt-Regamey et al., 2017; IUCN, 2018), the tool evaluation approach and the choice architecture we propose in this current study is based on the systematic identification of user preferences, for which we used the Delphi method. However, while useful to elicit knowledge and preferences, the Delphi method cannot be used as the only source of information to develop criteria for tool selection. The participants' backgrounds introduce some subjectivity, as all were AfriMAB meeting attendants and hence have a stated interest and a deep knowledge of the challenges of managing Biosphere Reserves. Furthermore, in Delphi, the anonymity of respondents may introduce a lack of accountability; and a Delphi should ideally be combined with quantitative data collection to assess the representativeness of some opinions. The Delphi method allows to collect both the individual and the collective intelligence of the participants, and is suited in situations where there is a lack of established facts and when a consensus needs to be found on complex issues. The number of participants $(n=22)$ that completed the two Delphi rounds is within the range of other Delphi studies (between 8 and 46 participants (Mukherjee et al., 2015)). To obtain a more comprehensive picture of the different stakeholders' expectations regarding ecosystem services assessment tools, ideally a larger number of potential users should be contacted. It is also striking that no AfriMAB attendants from the NGO or private sector replied to the survey - however this could be explained by their very low numbers at the 
meeting. In order to harness the power of live group discussions while simultaneously ensuring that tool quality criteria can be prioritized, a series of Nominal Group Technique-applications and follow-up Delphis could be useful in the future. Furthermore, given the diversity of direct and indirect beneficiaries of ecosystem services provided by African Biosphere Reserves, the pool of indirect tool users (or at least of people whose lives can be impacted by the uptake of the findings of the proposed tools) should be widened, and they should ideally be included in tool selection processes.

When evaluating a range of tools $(\mathrm{n}=17)$, one is unavoidably confronted by the challenges of presenting dense information in a user-friendly yet systematic way. While tables outlining the characteristics of tools are a common presentation format (e.g. in Bagstad et al., 2013, Pandeya et al., 2016; IUCN, 2018), arrows depicting successive (ever more in-depth) steps in the process of ecosystem services assessment (as in Bagstad et al., 2013) are also used. Every tool classification system also emphasizes different aspects of the tools, depending on the scope of the analysis and the preferences of the authors: Pandeya et al. (2016) classify tools based on their valuation approaches; Grêt-Regamey et al. (2017) classify tools based on their spatial scales, while IUCN classifies tools (among others) based on the underlying reasons to measure ecosystem services (e.g. private sector engagement, funding and investment, knowledge generation).

In this study we have avoided the use of a decision-tree to guide users to the most suited tool (contrary to e.g. IUCN (2018)), and instead provide four 'lenses' to select a tool in our visualization (Figures 2-5), allowing prospective tool users to base their selection on the required input data, the expected output, the required skills and/or the types of ecosystem services addressed by the tool. In Table 4, the overall purpose of each tool is added, as are the time requirements. In doing so we chose not to pre-empt the selection process of the users.

Inevitably, making choices regarding which criteria are deemed most relevant and useful to select a tool involves a reduction of all possible criteria that are found in the literature. The user expectations guided the selection of criteria, while existing literature provided fine-tuning.

The lack of coordination between tool developers and practitioners is an enduring problem, already identified by Bagstad et al. (2013), which is however hard to avoid due to the innovative, opensource character of many tools. A pragmatic approach to ecosystem services assessment tools ideally requires a search for synergies between external and local learning objectives and hence may require the combination of different (part of) tools (Van Noordwijk et al., 2013). For example, combining field data with existing environmental datasets improves the quality of ecosystem services maps (Martinez-Harms et al., 2016). For example, the TESSA-tool's preliminary scoping appraisal could be used to get a general overview of ecosystem services state and trends, by convening a number of participatory workshops. The TESSA-workshops typically yield a list of priority ecosystem services. The dynamics of these priority ecosystem services could then be modelled using, e.g. the InVEST tool, while PA-BAT could be applied to estimate their economic value. ESP-VT could be applied to visualize the ecosystem services findings, which would facilitate communication to a wider public. A flexible yet informed, cherry-picking approach to tools application can be justified by data requirements, data availabilities and by the urgency to present decision-makers with ecosystem services information in a timely manner.

\subsection{The African Biosphere Reserve context}

While ecosystem services assessment tools can in theory be used everywhere, many tools come with restrictions that cannot easily be ignored. The challenges of African Biosphere Reserves, as identified by the Delphi respondents (see Section 3.2.2) highlight lack of human and data resources. While these user-identified management challenges do not provide completely new information (e.g. compared to German Agency for Nature Conservation (2011)), the consensus levels indicate the priorities of the 
respondents. As suggested by Kratzer \& Ammering (2019), Biosphere Reserves may provide the institutional framework for rural social innovations - which could address some of the identified management challenges. Some ecosystem services assessment tools require input of existing datasets which may be incomplete, reflecting the geographic bias in ecological research and the comparative neglect of Africa (DiMarco et al., 2017), and/or reflecting the lack of centralized and accessible data repositories, despite the ongoing efforts of among others, the Clearing House Mechanism (CHM) of the Convention of Biological Diversity. Some tools may require skills that are not widely distributed in the rural areas of Africa, where most of the African Biosphere Reserves are located. Especially ground truthing, the economic valuation of biodiversity and the application of modern technologies in biodiversity monitoring are lacking in the global South (Vanhove et al., 2017). Some tools were initially developed with a non-African context in mind (such as CLIMSAVE with its European focus or the i-Tree-Eco set of tools, which have a USAfocus). This does not necessarily mean these tools are not applicable in an African context, however data availability may be an obstacle. The IDSD-tool on the other hand, has been developed with a Tanzanian context in mind (Fegraus et al., 2012).

Next to the specific data and capacity challenges, the direct dependence of many stakeholders on ecosystem services provided by Biosphere Reserves highlights the need to explicitly acknowledge the perceptions of ecosystem services' providers and beneficiaries (Pandeya et al., 2016), and to measure and monitor stakeholders' expectations and perceptions about ecosystem services use and trends. This is especially relevant in a context of increasing human pressure in and around African Biosphere Reserves as identified by the Delphi respondents. A tool like SOLVES focuses specifically on stakeholder perceptions of non-monetary values ascribed to particular ecosystem services, the so-called social values of ecosystems. In total seven of the seventeen tools do require stakeholder engagement skills (see Figure 3) and hence take into account stakeholders' perceptions. The RESPA-tool (which lies outside the scope of this review) assesses stakeholders' familiarity with ecosystem services and their relative importance to them (Rey-Valette et al., 2017). While locals, often have context-specific knowledge of ecosystem services that is easily missed by modelling tools, their input and hence often long-term (informal) managers of ecosystem services is also essential to develop collaborative, socially robust solutions with large buy-in. This is an essential element of inclusive conservation, which encompasses different motivations for conservation, ranging from the intrinsic to the instrumental (Tallis \& Lubchenco, 2014; Chan et al., 2016). Given the exemplary function of African Biosphere Reserves as 'living labs' where inclusive sustainable development can be realized, any ecosystem services assessment tool that is used within this context should ideally be able to encompass the diversity of views on nature and its management. This de-polarizing approach to conservation and natural resource management is of utmost importance in the African context, where governance challenges remain pervasive, and where the threat of the militarisation of conservation is real (Duffy et al., 2019).

\subsection{From applying tools to influencing decision-making}

Applying carefully selected ecosystem services assessment tools based on a user's set of expectations is a first step, yet the ultimate objective is to have an impact on actual decisions, e.g. decisions related to the management of a Biosphere Reserve. Bridging the gap between science and policy by linking nature and human wellbeing is the stated aim of the ecosystem services concept (see e.g. Mace, 2014). This requires tool outputs that are easily communicated to decision-makers, and a capacity of decision-makers to take up and engage with these outputs. Decision-makers typically prefer a variety of ecosystem services metrics (Ruckelshaus et al., 2015), which may require the use of tools producing multiple outputs, or the combination of complementary tools (see also 
Section 4.1). In order to be useful to decision-makers, tools must be customizable (Martinez-Lopez et al., 2019) and must foster innovation. Experimentation (e.g. using modules originating from different tools) needs to be encouraged, hence the importance of freely available tools and supporting datasets. Training is required both at the data production side (scientists, managers, consultants applying the tools) and at the data uptake and translation side (decision-makers, managers). Transparent communication about the motivations underlying methodological choices is essential. Communicating uncertainty is key in order to ensure the credibility of rapid ecosystem services assessment tools and in order to allow for informed and flexible management trade-offs by decision-makers. However, Grêt-Regamey et al. (2017) state that almost half the tools their team reviewed do not quantify these uncertainties. The lack of maintenance and long-term availability of some tools and their online support is a risk, and a consequence of the often time-limited project-based funding of such tools. Uptake and institutionalization of these tools, for example by networks such as AfriMAB could contribute to solve this issue.

While most tools reviewed in this study have been extensively applied in the field, not all have been applied in Biosphere Reserves, and not all applications have been subject to scientific scrutiny. The INVEST tool applications have been reviewed by Ruckelshaus et al. (2015) and have had impact at different decision-making levels. The TESSA tool application for the Shivapuri-Nagarjun National Park in Nepal yielded estimates of avoided monetary loss thanks to conservation (Peh et al., 2016). In order to evaluate the range of impacts ecosystem services assessment tools can have on decisionmaking on the short- and the long-term, a more comprehensive model of tool effectiveness needs to be kept in mind, focusing on their substantial impact on well-defined decisions, as well as on their less directly measurable normative impact (e.g. tools fostering social learning and changing mind-sets) (Hugé et al., 2015). This requires tools that are suitable to incorporate stakeholders' perspectives on ecosystem services use, trends and management. Such tools ideally include accessible and graphic data collection methods (rich pictures, participatory mapping), and can also include serious games (Merlet $e t$ al., 2018). An increased awareness of the diversity of existing tools and guidance for prospective tool users will increase the number of applications of such tools and will consequently increase our understanding of their impact.

\section{Conclusion}

The diverse and dynamic landscape of ecosystem services assessment tools reflects the diversity of representations of the relationship between people and nature. Ecosystem services assessment tools typically start from a range of assumptions about what is important, what is measurable and what is urgent to address - and these assumptions differ between the teams developing the tools. This situation creates a rich landscape of tools in which potential tool users may find it difficult to navigate. The difficult trade-off between simple and complex approaches to ecosystem services assessment should not lead to inaction, as the diversity of tools and their respective strengths and coverage offer opportunities for users with different expectations to find the most suitable tool, while also providing inspiration for users aiming at developing new tools.

In this study, we presented a classification of ecosystem services assessment tools that are adapted to the context of African Biosphere Reserves, based on a combination of literature review and an iterative user survey. We proposed two 'tools to select tools': a Table and a series of visualizations which highlight the main components of a range of ecosystem services assessment tools (input data, output data, skills required, ecosystem services addressed covered, time constraints and purpose). There is no one-size-fits-all approach to ecosystem services assessment tools, and the resource-constrained context of African Biosphere Reserves creates extra challenges that will influence the tool selection process. Tools are not applied in a governance vacuum. Hence the impact of the application of such tools should not only be measured based on their technical quality, but also on their short- and long-term impact on actual decision-making - i.e. on the 
management of Biosphere Reserves. A range of tools that are discussed in this paper has been and/or is currently being applied within the frame of the EVAMAB project (http://www.biodiv.be/evamab), funded by the Belgian Scientific Policy (BELSPO) in collaboration with UNESCO. Given the strategic importance of African Biosphere Reserves as key sources of ecosystem services for a directly nature-dependent human population, and given the exemplarity of Biosphere Reserves as living labs for sustainable development, the sound selection and application of ecosystem services assessment tools takes on a particular urgency.

\section{Acknowledgements}

The authors wish to thank all Delphi participants. The authors acknowledge the financial support of the UNESCO MAB Programme and the Belgian Science Policy, within the frame of the EVAMAB project; the Belgian Development Cooperation for its support to CEBioS; the KLIMOS Acropolis Research Platform funded by the Flemish Inter-University Council - University Development Cooperation VLIR UOS; the Global Minds Post-Doctoral Fellowship Program of the Vrije Universiteit Brussel and VLIR UOS. This manuscript is one of the outputs of Work Package 1 of the EVAMAB Project (Economic valuation of ecosystem services in Biosphere Reserves: testing effective rapid assessment methods in selected African Biosphere Reserves).

\section{References}

Bagstad, K.J., Semmens, D.J., Waage, S. \& Winthrop, R., 2013. A comparative assessment of decision-support tools for ecosystem services quantification and valuation. Ecosystem Services 5: 27-39

Ball, I.R., H.P. Possingham, and M. Watts. 2009. Marxan and relatives: Software for spatial conservation prioritisation. Chapter 14: Pages 185-195 in Spatial conservation prioritisation: Quantitative methods and computational tools. Eds Moilanen, A., K.A. Wilson, and H.P. Possingham. Oxford University Press, Oxford, UK.

Cardinale, B.D., Duffy, E., Gonzalez, A., Hooper, D.U., Perrings, C., Venail, P., Narwani,_A., Mace, G.M., Tilman, D., Wardle, D.A., Kinzig, A.P., Daily, G.C., Loreau, M., Grace,_J.B., Larigauderie, A., Srivastava, D.S. \& Naeem, S., 2012. Biodiversity loss and its_impact on humanity. Nature 486: $49-57$

CBD 2004. The ecosystem approach. CBD Guidelines. Secretariat of the Convention on Biological Diversity. https://www.cbd.int/doc/publications/ea-text-en.pdf Last accessed on September 30, 2019.

Chan, K., Balvanerab, P., Benessaiah, K., Chapman, M., Diaz, S., Gomez-Baggethune, E., Gould, R., Hannahs, N., Jax, K., Klain, S., Luck, G., Martin-Lopez, B., Muraca, B., Norton, B., Ott, K., Pascualo, U., Satterfield, T., Tadaki, M., Taggart, J. \& Turner, N. 2016. Why protect nature? Rethinking values and the environment. PNAS 113: 1462-1465.

Costanza, R., de Groot, R., Braat, L., Kubiszewski, I., Fioramonti, L., Sutton, P., Farber, S. \& Grasso, M. 2017. Twenty years of ecosystem services: how far have we come and how far do we still need to go? Ecosystem Services 28: 1-16.

Co\$ting Nature, 2018 http://www.policysupport.org/costingnature. Last accessed March 1 ${ }^{\text {st }}$, 2019. 
Cuong, C.V., Dart, P. \& Hockings, M. 2017. Biosphere reserves: attributes for success. Journal of Environmental Management 188: 9-17.

Díaz, Unai Pascual, Marie Stenseke, Berta Martín-López, Robert T. Watson, Zsolt Molnár, Rosemary Hill, Kai M. A. Chan, Ivar A. Baste, Kate A. Brauman, Stephen Polasky, Andrew Church, Mark Lonsdale, Anne Larigauderie, Paul W. Leadley, Alexander P. E., van Oudenhoven, Felice van der Plaat, Matthias Schröter, Sandra Lavorel, Yildiz Aumeeruddy-Thomas, Elena Bukvareva, Kirsten Davies, Sebsebe Demissew, Gunay Erpul, Pierre Failler, Carlos A. Guerra, Chad L. Hewitt, Hans Keune, Sarah Lindley, Yoshihisa Shirayama, 2018. Assessing nature's contributions to people. Recognizing culture, and diverse sources of knowledge, can improve assessments. Science 359 (6373): 270-272

Di Marco, M., Chapman, S., Althor, G., Kearney, S., Besancon, C. „Butt, N., Maina, J.M., Possingham, H.P., Rogalla von Bieberstein, K., Venter, O. \& Watson, J.E.M. 2017. Changing trends and persisting biases in three decades of conservation research. Global Ecology \& Conservation 10: 32-42

Drakou, E.G., Crossman, N.D., Willemen, L., Burkkhard, B., Palomo, I., Maes, J., Peedell, S. 2015. A visualization and data-sharing tool for ecosystem service maps: Lessons learnt, challenges and the way forward. Ecosystem Services 13: 134-140

Dudley, N. \& Stolton, S. 2009. The Protected Areas Benefits Assessment Tool. A methodology. WWF World Wide Fund for Nature. Gland, Switzerland.

Duffy, R., Massé, F. Smidt, EM, Marijnen, E., Büscher, B., Verweijen, J., Ramutsindela, M., Simlai, T., Joanny, L. \& Lunstrum, E. 2019. Why we must question the militarisation of conservation. Biological Conservation 232: 66-73

Duku, C., Rathjens, H., Zwart, S.J. \& Hein, L. 2015. Towards ecosystem accounting: a comprehensive approach to modelling multiple hydrological ecosystem services. Hydrology and Earth System Sciences 19: 4377-4396

Estoque, R.C. \& Murayama, Y. 2012. Examining the potential impact of land use/cover changes on the ecosystem services of Baguio city, the Philippines: A scenario-based analysis. Applied Geography 35: 316-326

Fegraus, E.H., Zaslavsky, I., Whitenack, T., Dempewolf, J., Ahumada, J.A., Lin, K. \& Andelman, S.J. 2012. Interdisciplinary Decision Support Dashboard: A New Framework for a Tanzanian Agricultural and Ecosystem Service Monitoring System Pilot. IEEE Journal of Selected Topics in Applied Earth Observations and Remote Sensing, 5(6): 1700-1708:

Fisher, J.A., Patenaude, G., Giri, K., Lewis, K.; Meir, P., Pinho, P., Rounsevell, M.D.A. \& Williams, M. 2014. Understanding the relationships between ecosystem services and poverty alleviation: a conceptual framework. Ecosystem Services 7: 34-45

German Federal Agency of Nature Conservation 2011. Report of the International Expert Workshop on 'Managing Challenges of Biosphere Reserves in Africa'. Available at: https://www.bfn.de/fileadmin/MDB/documents/themen/internationalernaturschutz/2011 Afr iBR DiscussionResults.pdf. Last accessed March 9, 2018.

Grêt-Regamey, A., Sirén, E., Brunner, S.H. \& Weibel, B., 2017. Review of decision support tools to operationalize the ecosystem services concept. Ecosystem Services 26: 306-315 
Hanson, C., J. Ranganathan, C. Iceland, \& Finisdore, J. 2012. The Corporate Ecosystem Services Review: Guidelines for Identifying Business Risks and Opportunities Arising from Ecosystem Change. Version 2.0. Washington, DC: World Resources Institute.

Harrison, P.A., Holman, I.P. \& Berry, P.M. 2015. Assessing cross-sectoral climate change impacts, vulnerability and adaptation: an introduction to the CLIMSAVE project. Climatic Change 128: 153-167

Helmholtz Centre for Environmental Research-UF, Leipzig, 2018. SITE. www.ufz.de/index.php?en=19080. Last accessed January 20, 2019.

Hugé, J., Mukherjee, N., Fertel, C., Waaub, J.P., Block, T., Waas, T., Koedam, N. \& DahdouhGuebas, F. 2015. Conceptualizing the effectiveness of sustainability assessment in development cooperation. Sustainability 7: 5735-5751

Hugé, J., Van Puyvelde, K., Munga, C., Dahdouh-Guebas, F. \& Koedam, N. 2018. Exploring coastal development scenarios for Zanzibar: a local microcosm-inspired Delphi study. Ocean \& Coastal Management 158: 83-92.

IPBES 2018. Summary for policymakers of the regional assessment on biodiversity and ecosystem services for Africa of the Intergovernmental Science-Policy Platform on Biodiversity \& Ecosystem Services. IPBES Secretariat. Bonn, Germany.

IPBES 2019. https://www.ipbes.net/glossary/ecosystem-services. Intergovernmental SciencePolicy Platform on Biodiversity \& Ecosystem Services. Bonn, Germany. Last accessed September 30, 2019.

IUCN 2018. Tools for measuring, modelling and valuing ecosystem services. Guidance for Key Biodiversity Areas, natural World Heritage Sites, and protected areas. Best Practices Protected Areas Guidelines $N^{\circ} 28$. Gland, Switzerland.

Kratzer, A. \& Ammering, U. Rural innovations in biosphere reserves - a social network approach. Journal of Rural Studies 71: 144-155

Landsberg, F., S. Ozment, M. Stickler, N. Henninger, J. Treweek, O. Venn, and G. Mock 2011. Ecosystem Services Review for Impact Assessment: Introduction and Guide to Scoping. WRI Working Paper. World Resources Institute, Washington DC, USA

Landsberg, F., Treweek, J., Stickler, M.M., Henninger, N. \& Venn, O. 2014. Weaving ecosystem services into impact assessment. A step-by-step method. World Resources Institute, Washington DC, USA.

Mace, G.M. 2014. Whose conservation? Science 345: 1558-1560

Maes, J., Hauck, J., Paracchine, M, L., Ratamaki, O., Hutchins, M., Termansen, M., Furman, E., Perez-Soba, M., Braat, L. \& Bidoglio, G. 2013. Mainstreaming ecosystem services into EU policy. Current Opinion in Environmental Sustainability 5: 128-134

Maron, M., Mitchell, M.G.E., Runting, R.K., Rhodes, J.R., Mace, G.M., Keith, D.A. \& Watson, J.E.M. 2017. Towards a threat assessment framework for ecosystem services. Trends in Ecology \& Evolution 32: 240-248

Martinez-Harms, M.J., Quijas, S., Merenlender, A. \& Balvanera, P. 2016. Enhancing ecosystem services maps combining field and environmental data. Ecosystem Services 22: 32-40 
Martinez-Lopez, J., Bagstad, K.J., Balbi, S., Magrach, A., Voigt, B., Athansiadis, I., Pascual, M., the Total Environment 650: 2325-2336

Merlet, P., Van Hecken, G. \& Rodriguez-Fabilena, R. 2018. Playing before paying? A PES simulation game for assessing power inequalities and motivations in the governance of ecosystem services. Ecosystem Services 34B: 218-227

Mukherjee N., Sutherland, W..J., Dicks, J., Hugé, J., Koedam, N. \& Dahdouh-Guebas, F. 2014. Ecosystem services valuation of mangrove ecosystems to inform decision-making and future valuation exercises. PLOS One 9 (9): e107706

Mukherjee, N., Hugé, J., Sutherland, W., McNeill, J., Van Opstal, M., Dahdouh-Guebas, F. \& Koedam, N. 2015. The Delphi technique in ecology and biological conservation: applications and guidelines. Methods in Ecology \& Evolution 6: 1097-1109

Myers, M., Mittermeier, R.E., Mittermeier, C.G., da Fonseca, G.A.VB \& Kent, J. 2000. Biodiversity hotspots for conservation priorities. Nature 403: 853-858

Natural Economy Northwest, CABE, Natural England, Yorkshire Forward, The Northern Way, Design for London, Defra, Tees Valley Unlimited, Pleasington Consulting Ltd, and Genecon LLP (2010). Building natural value for sustainable economic development: Green Infrastructure Valuation Toolkit. Version 1.4. http://bit.ly/givaluationtoolkit. Last accessed March 1st, 2019.

Oosterbroek, B., de Kraker, J., Huynen, M.M.T.E. \& Martens, P. 2016. Assessing ecosystem impacts on health: a tool review. Ecosystem Services 17: 237-254

Pagella, T.F., Sinclair, F.L., 2014. Development and use of a typology of mapping tools to assess their fitness for supporting management of ecosystem service provision. Landscape Ecology 29: 383-399

Pandeya, B., Buytaert, W., Zulkafli, Z., Karpouzoglou, T., Mao, F. \& Hannah, D.M. 2016. A comparative analysis of ecosystem services valuation approaches for application at the local scale and in data scarce regions. Ecosystem Services 22, Part B: 250-259

Peh, K.S.-H., Balmford, A., Bradbury, R.B., Brown, C., Butchart, S.H.M., Hughes, F.M.R., Stattersfield, A., Thomas, D.H.L., Walpole, M., Bayliss, J., Gowing, D., Jones, J.P.G., Lewis, S.L., Mulligan, M., Pandeya, B., Stratford, C., Thompson, J.R., Turner, K., Vira, B., Willcock, S., Birch, J.C., 2013. TESSA: A toolkit for rapid assessment of ecosystem services at sites of biodiversity conservation importance. Ecosystem Services 5: 51-57

Peh, K.S-H., Thapa, I., Basnyat, M., Balmford, A., Bhattarai, G.P., Bradbury, R.P., Brown, C., Butchart, S.H.M, Dhakal, M., Gurung, H., Hughes, F.M.R, Mulligan, M., Pandeya, B., Sattersfield, A.J., Thomas, D.H.L, Walpole, M. \& Merriman, J.C. 2016. Synergies between biodiversity conservation and ecosystem service provision: lessons on integrated ecosystem service valuation from a Himalayan protected area, Nepal. Ecosystem Services 22: 359-369

Pool-Stanvliet, R., Stoll-Kleemann, S. \& Giliomee, J.H. 2018. Criteria for selection and evaluation of Biosphere Reserves in support of the UNESCO MAB programme in South Africa. Land Use Policy 76: 654-663

Rey-Valette, H., Mathé, S. \& Salles, J.M. 2017. An assessment method of ecosystem services based on stakeholders' perceptions: the Rapid Ecosystem Services Participatory Appraisal (RESPA). Ecosystem Services 28: 311-319 
Ruckelshaus, M., McKenzie, E., Tallis, H., Guerry, A., Daily, G. \& Kareiva, P. 2015. Notes from the field: lessons learned from using ecosystem services approaches to inform real-world decisions. Ecological Economics 115: 11-21

Sherrouse, B.C. \& Semmens, D.J. 2015. Social values for ecosystem services, version 3.0 (SolVES 3.0)—Documentation and user manual: U.S. Geological Survey (USGS) Open-File Report 20151008.

Steffen, W., Richardson, K., Rockström, J., Cornell, S.E., Fetzer, I., Bennett, E.M., Biggs, R., Carpenter, S.R., de Vries, W., de Wit, C.A., Folke, C., Gerten, D., Heinke, J., Mace, G.M., Persson, L.M., Ramanathan, V., Reyers, B. \& Sörlin, S. 2015. Planetary boundaries: guiding human development on a changing planet. Science 347: 736

Suich, H., Howe, C. \& Mace, G. 2015. Ecosystem services and poverty alleviation: a review of the empirical links. Ecosystem Services 12: 137-147

Tallis, H. \& Lubchenco, J. 2014. A call for inclusive conservation. Nature 515: 27-28

Tallis H.T. 2013. InVEST tip User's Guide: Integrated Valuation of Environmental Services and Trade-offs. A modeling suite developed by the Natural Capital Project. www.naturalcapitalproject.org. Last accessed March $1^{\text {st }}, 2019$.

Turner, K.G., Anderson, S., Gonzales-Chang, M., Costanza, R., Courville, S., Dalgaard, T., Dominati, E., Kubiszewski, I., Ogilvy, S., Porfirio, L., Ratna, N., Sandhu, H., Sutton, P.C., Svenning, J.-C., Turner, G.M., Varennes, Y.-D., Voinov, A. \& Wratten, S. 2016. A review of methods, data, and models to assess changes in the value of ecosystem services from land degradation and restoration. Ecological Modelling 319, 190-207

UN 2019. World Population Prospects 2019. Department of Economic \& Social Affairs. New York, USA. https://population.un.org/wpp/Publications/Files/WPP2019 Highlights.pdf. Last accessed September 29, 2019.

UN CDP 2018. List of Least Developed Countries (as of December 2018). https://www.un.org/development/desa/dpad/wpcontent/uploads/sites/45/publication/ldc lis t.pdf. Last accessed January 5, 2020.

UNESCO 2016. Man and the Biosphere Program. http://www.unesco.org/new/en/naturalsciences/environment/ecological-sciences/man-and-biosphere-programme/about-mab/ Last accessed September 30, 2019.

USDA 2015 .i-TreeEco. http://www.itreetools.org/eco/. Last accessed March 1 1", 2019.

ValuES Project : Methods for integrating ecosystem services into policy, planning, and practice. Accessible on www.aboutvalues.net/ Last accessed March 1" 2019.

Vanhove, M.P.M., Rochette, A.J. \& Janssens de Bisthoven, L. 2017. Joining science and policy in capacity development for monitoring progress towards the Aichi Biodiversity Targets in the global South. Ecological Indicators 73: 694-697

Van Noordwijk M, Lusiana B, Leimona B, Dewi S, Wulandari D, eds. 2013. Negotiation-support toolkit for learning landscapes. Bogor, Indonesia: World Agroforestry Centre (ICRAF) Southeast Asia Regional Program. 
van Oudenhoven, A., Aukes, E., Bontje, L.E., Vikolainen, V., van Bodegom, P. \& Slinger, J.H. 2018. 'Mind the gap' between ecosystem services classification and strategic decision making. Ecosystem Services 33: 77-88.

Villa, F., Bagstad, K.J., Voigt, B., Johnson, G.W., Portelas, R., Honzaks, M. \& Batker, D. 2014. A methodology for adaptable and robust ecosystem services assessment. PLOS One 9(3): e91001. doi:10.1371/journal.pone.0091001

Von der Gracht, H.A. 2012. Consensus measurement in Delphi studies. Technological Forecasting \& Social Change 79: 1525-1536

WWF \& Dalberg 2013. The economic value of Virunga National Park. WWF International. Gland, Switzerland. 


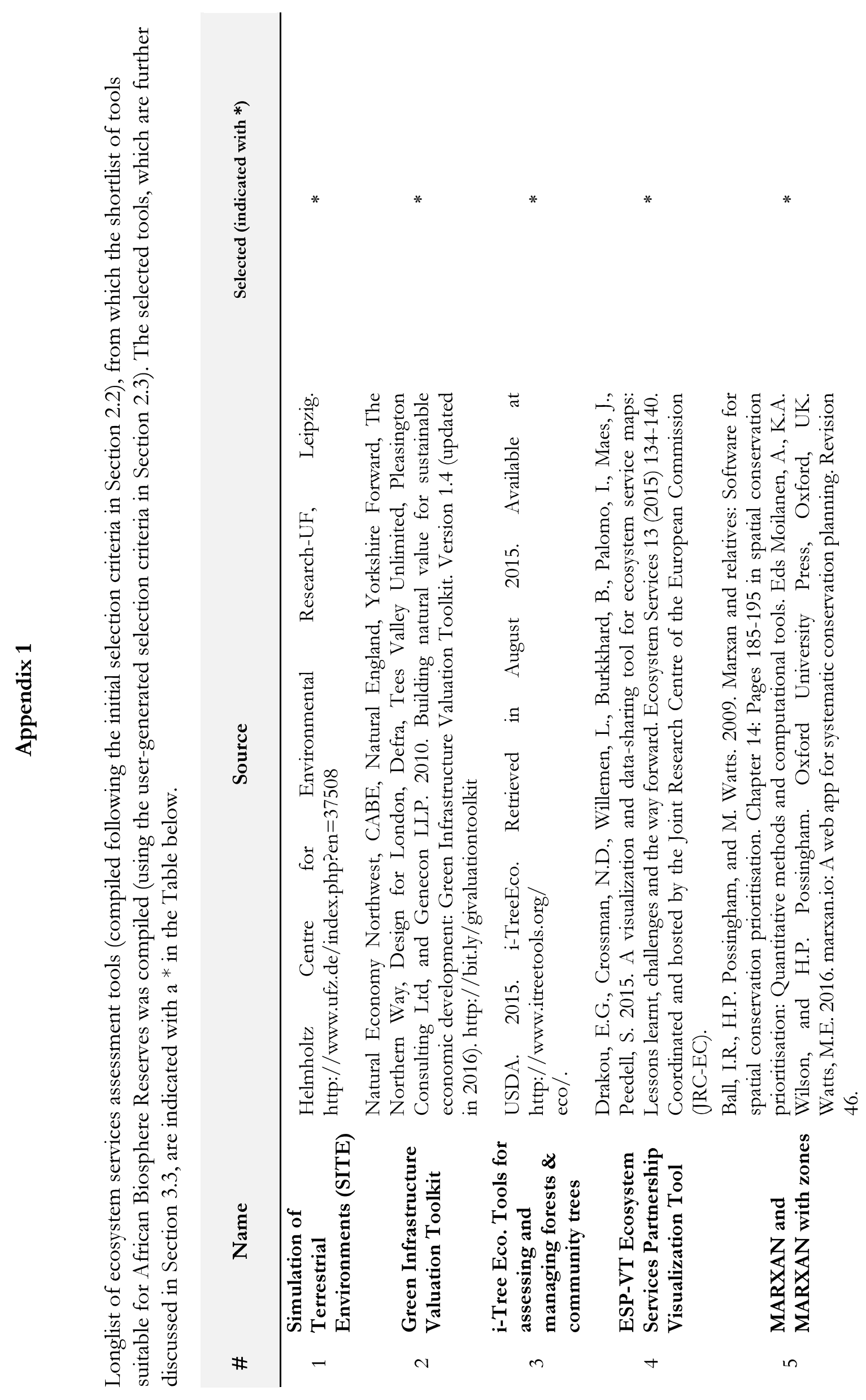




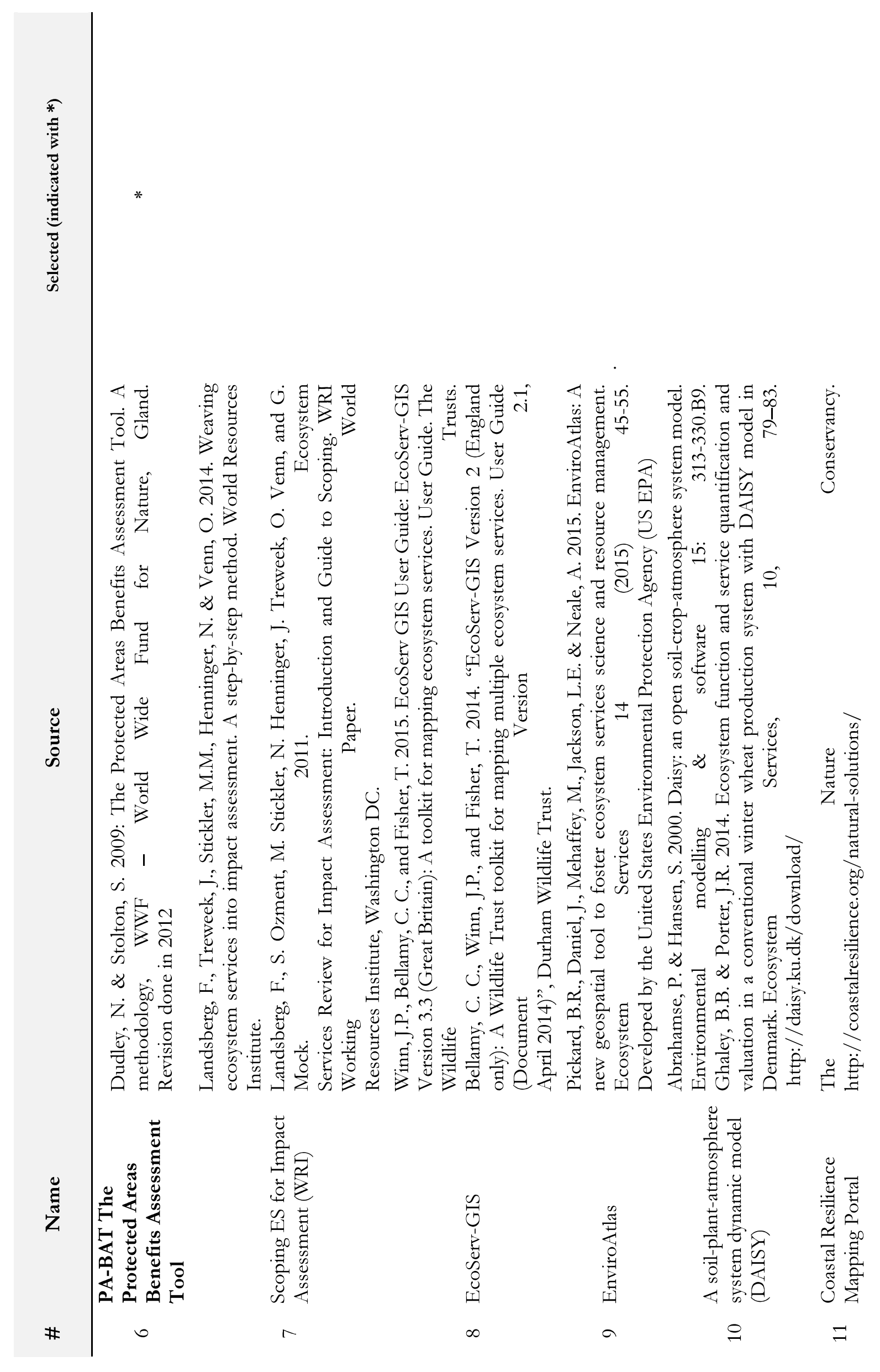




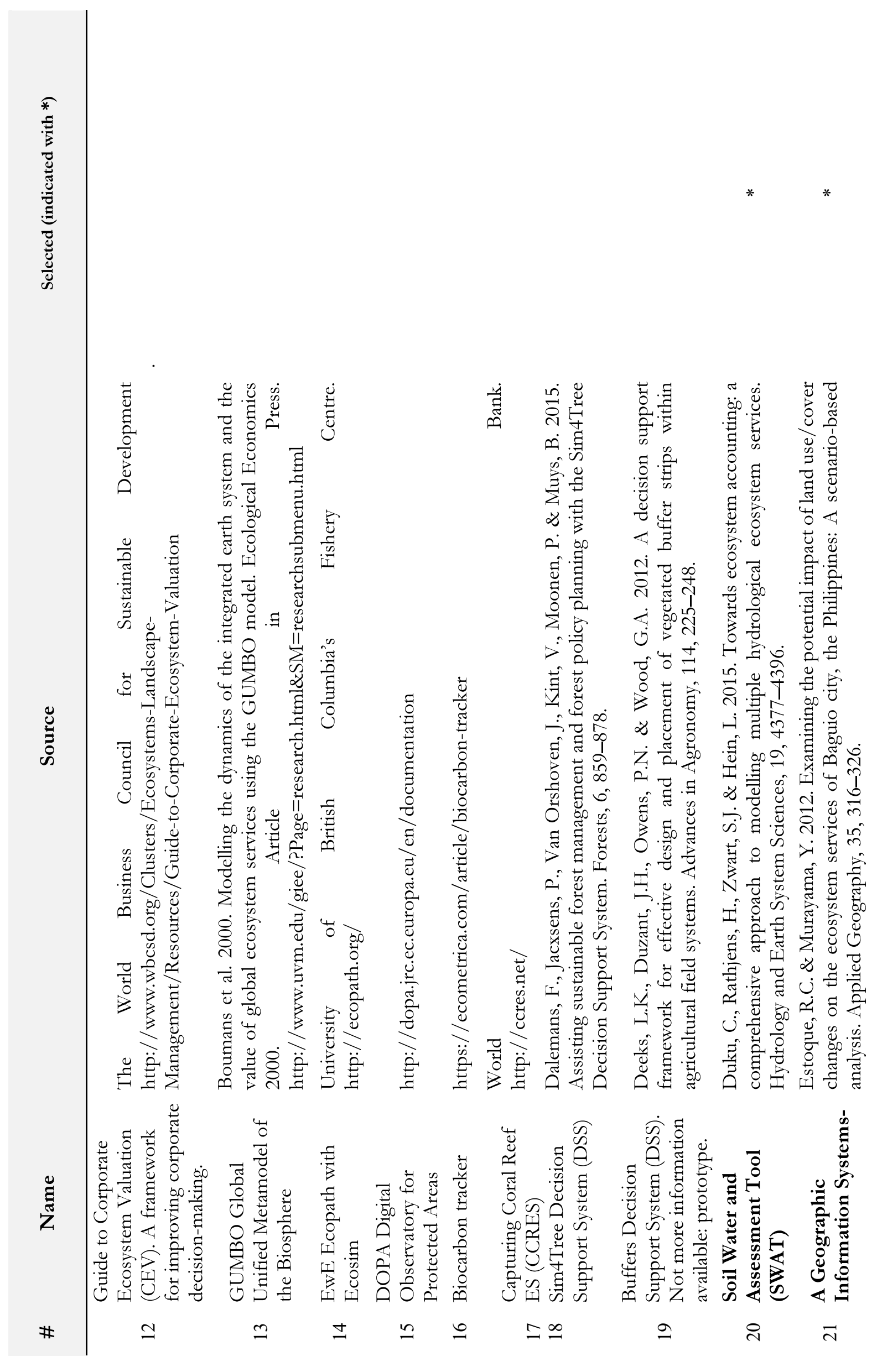




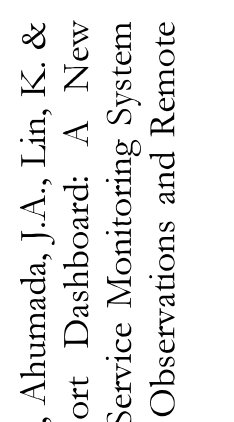

$\therefore$ 员

出芯芯专

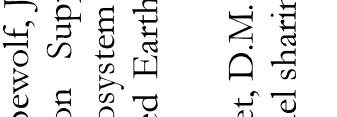

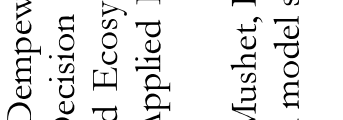

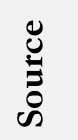

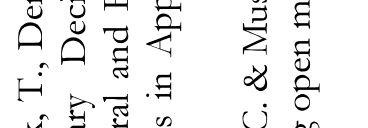

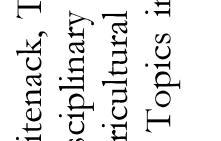

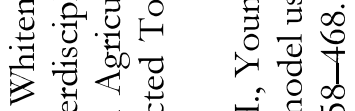

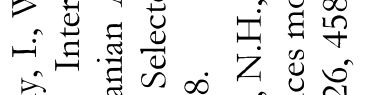
究

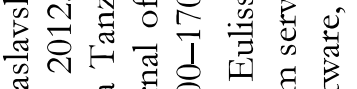

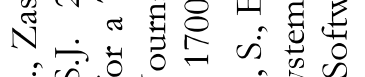

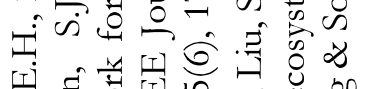

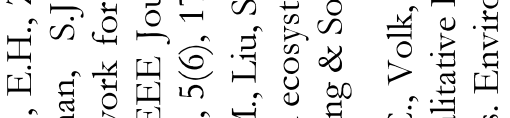

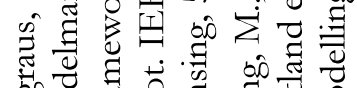

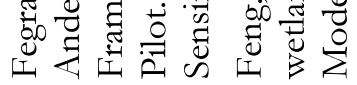

矛出

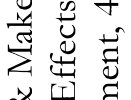

กิ

Q

空

$\hat{i} \cdot \frac{\pi}{2}$

$\Delta, \frac{0}{5}$

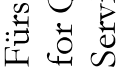

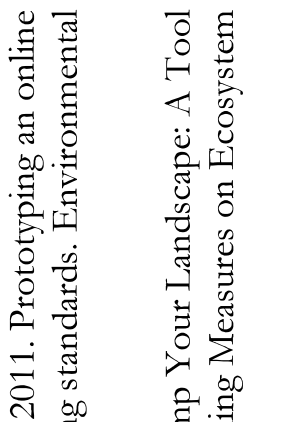

畐 青

ำ สี

घี

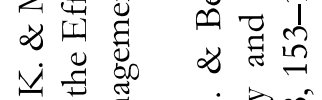

ड़

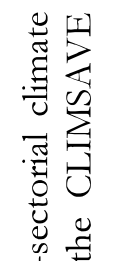

0
0
0
0

番.

离

윻ำ

我

爮密它

$\infty$ च चू

ค: 预

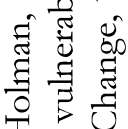

<

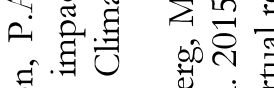

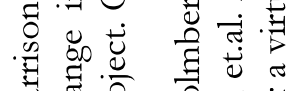

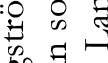

至.

iิ

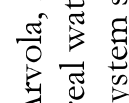

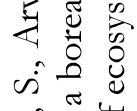

กึ

专. 胥

दे क्ज

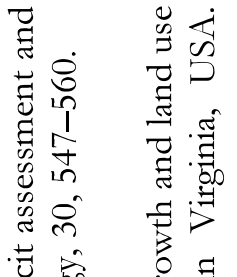

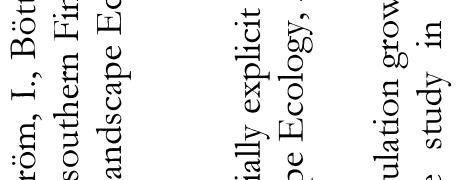

तथ के

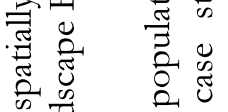

至

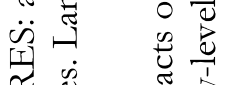

帘.

害

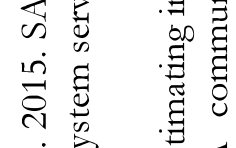

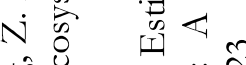

की

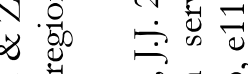

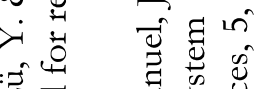

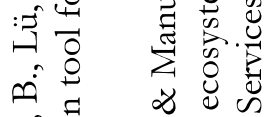

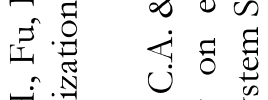

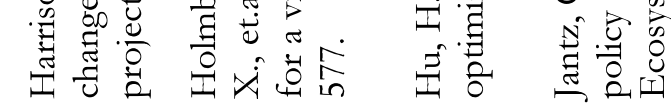

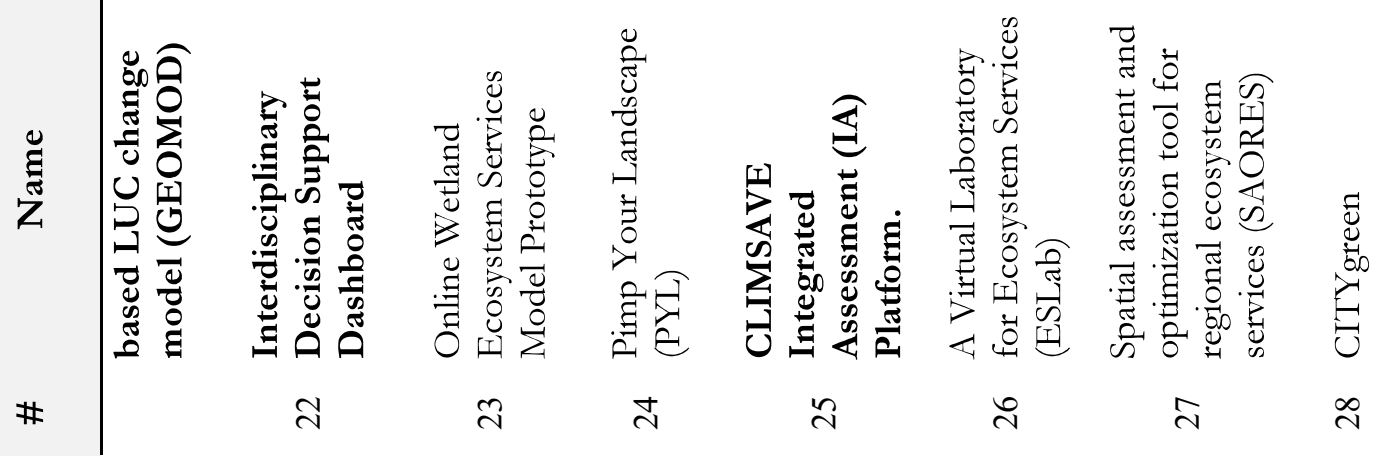




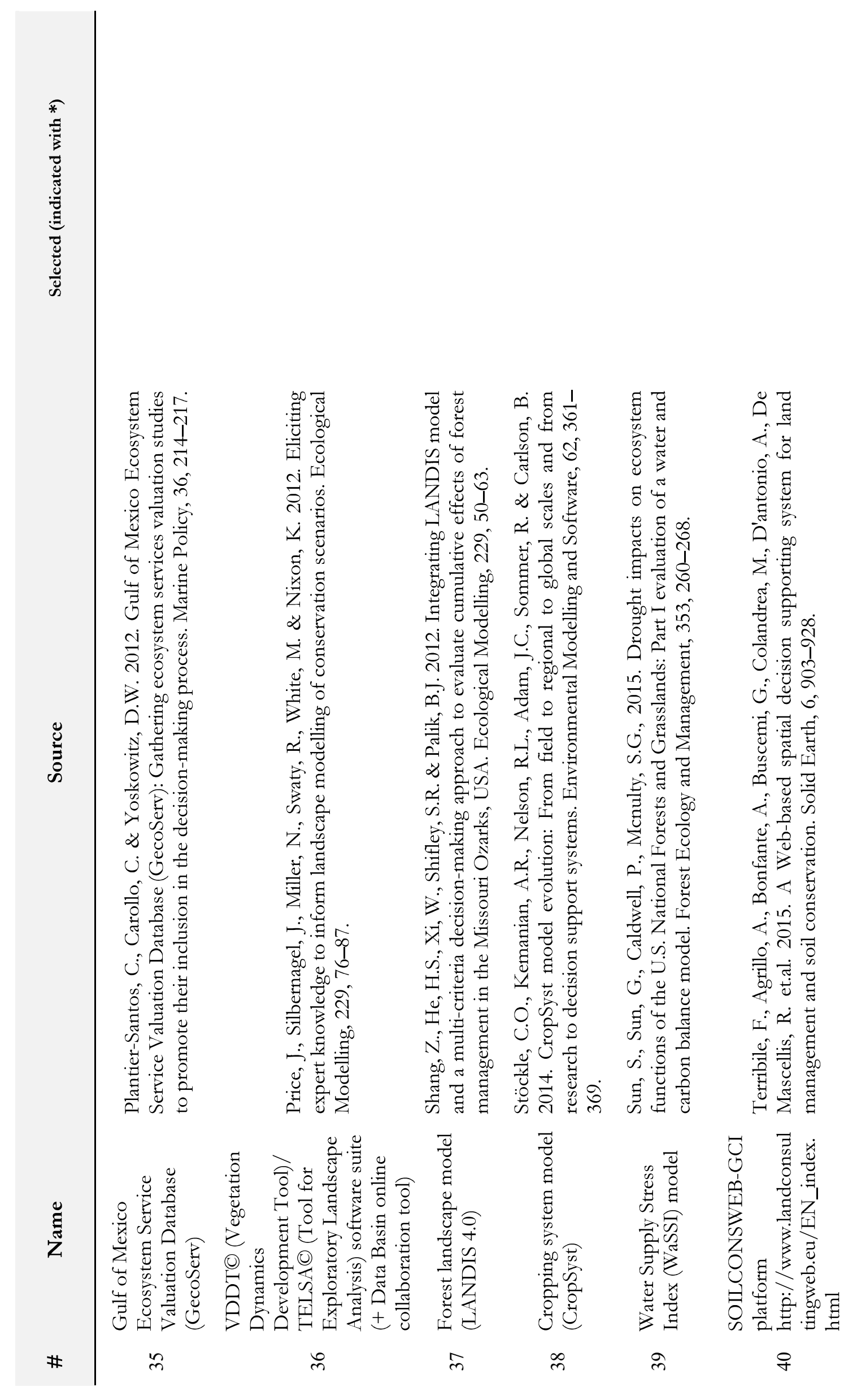

$\vec{m}$ 


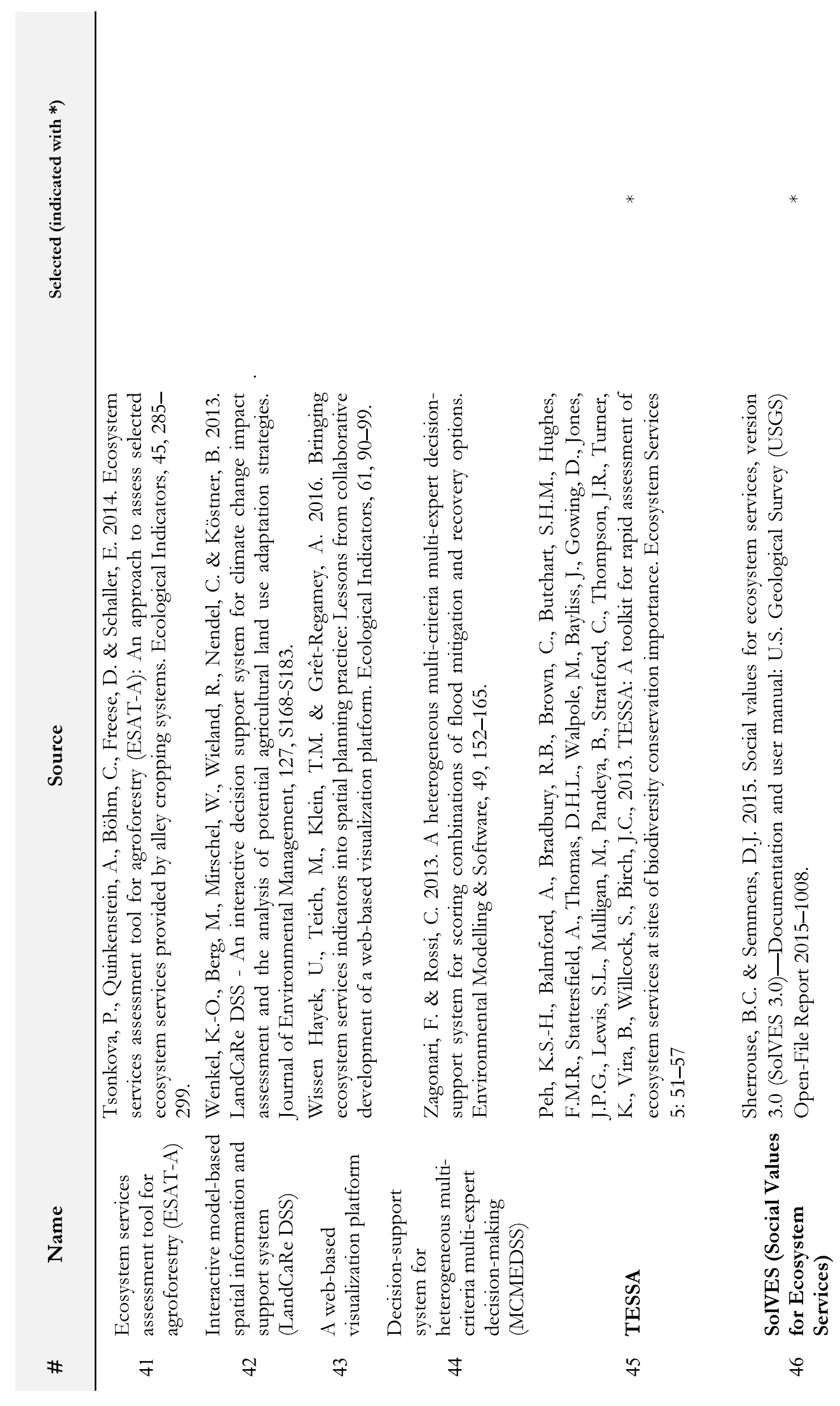

กี 


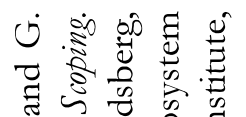

ำ

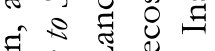

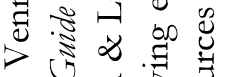

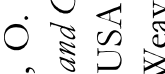
s

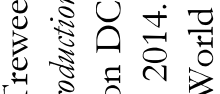
$\therefore$.

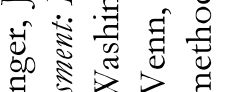
窎事 $>$

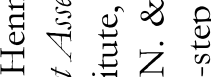

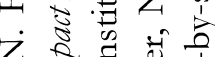
चे 造造造

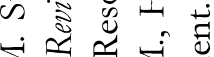

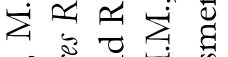

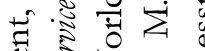

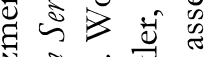
Oิ का है की की

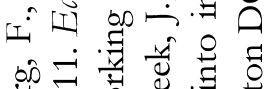
की

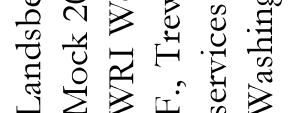

\begin{tabular}{|c|c|c|}
\hline 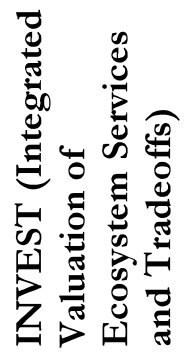 & 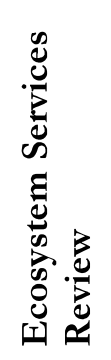 & 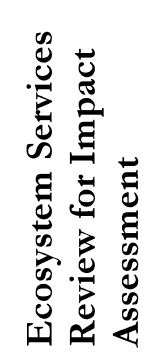 \\
\hline gे & in & \\
\hline
\end{tabular}



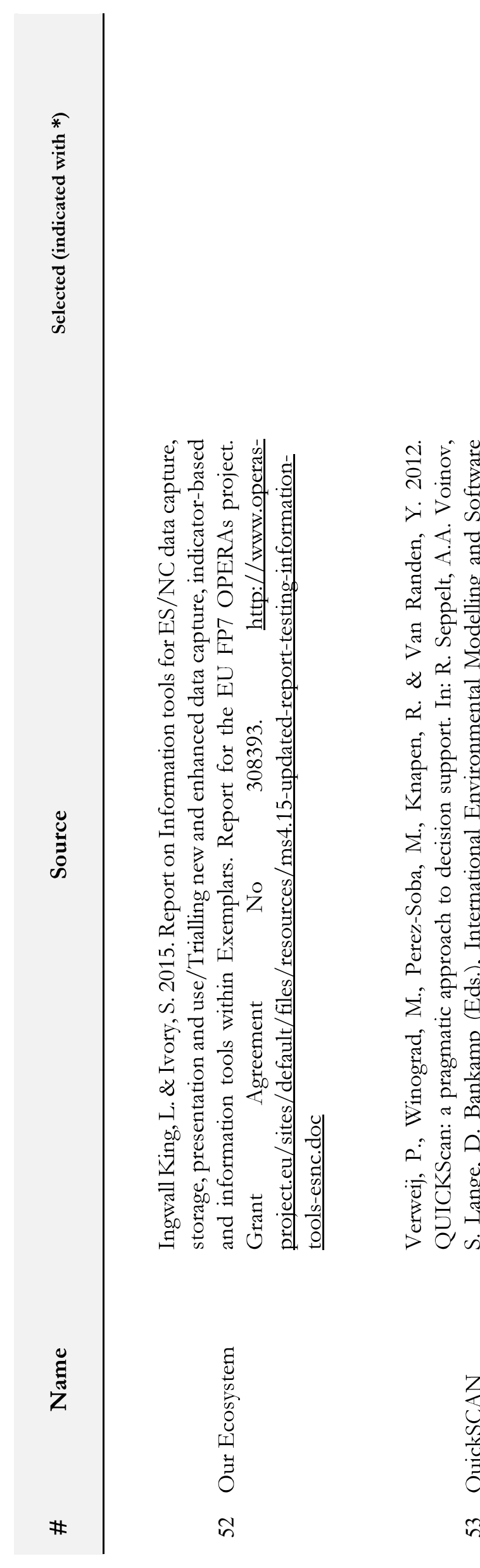

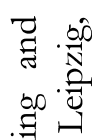

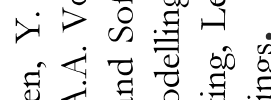

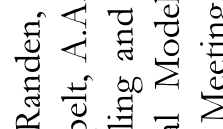

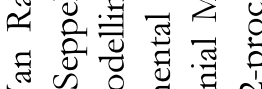

$\infty$ \&

め)

वी

矛莒.

部

‡

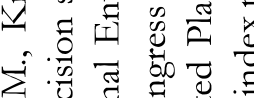

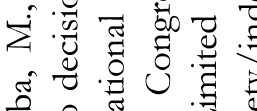

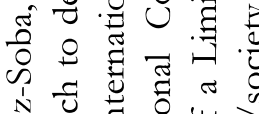

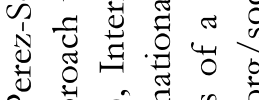

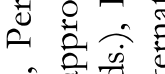

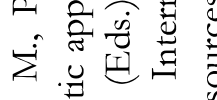

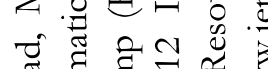

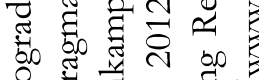

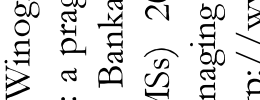

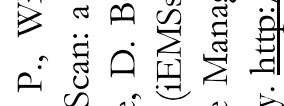

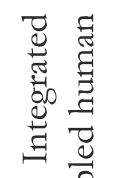

त्र

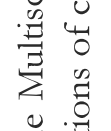

造

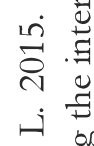

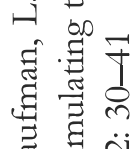

岂茪

\&

甜运富

兒总

¿.

हี हี

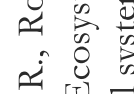

幽可

:矛芯芯壳言

苛

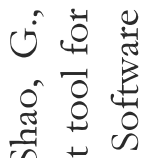

क

늘

㻤

$\dot{4}$ 栗

点芯

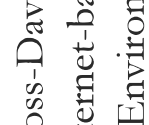

点 志

$\therefore$ 平

ปี

صथ

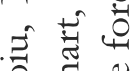

永

光占蛋

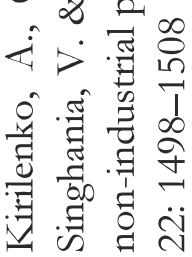




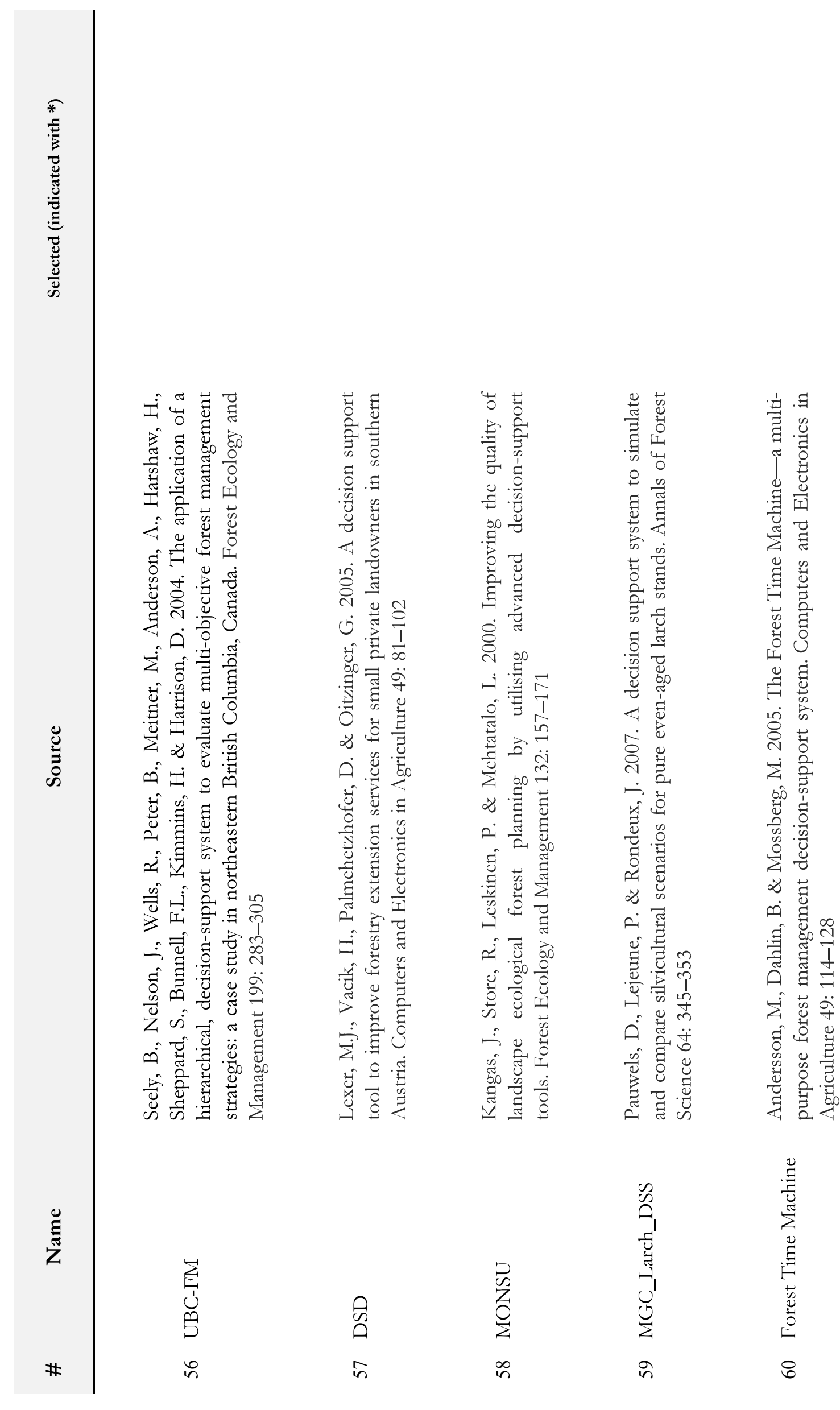




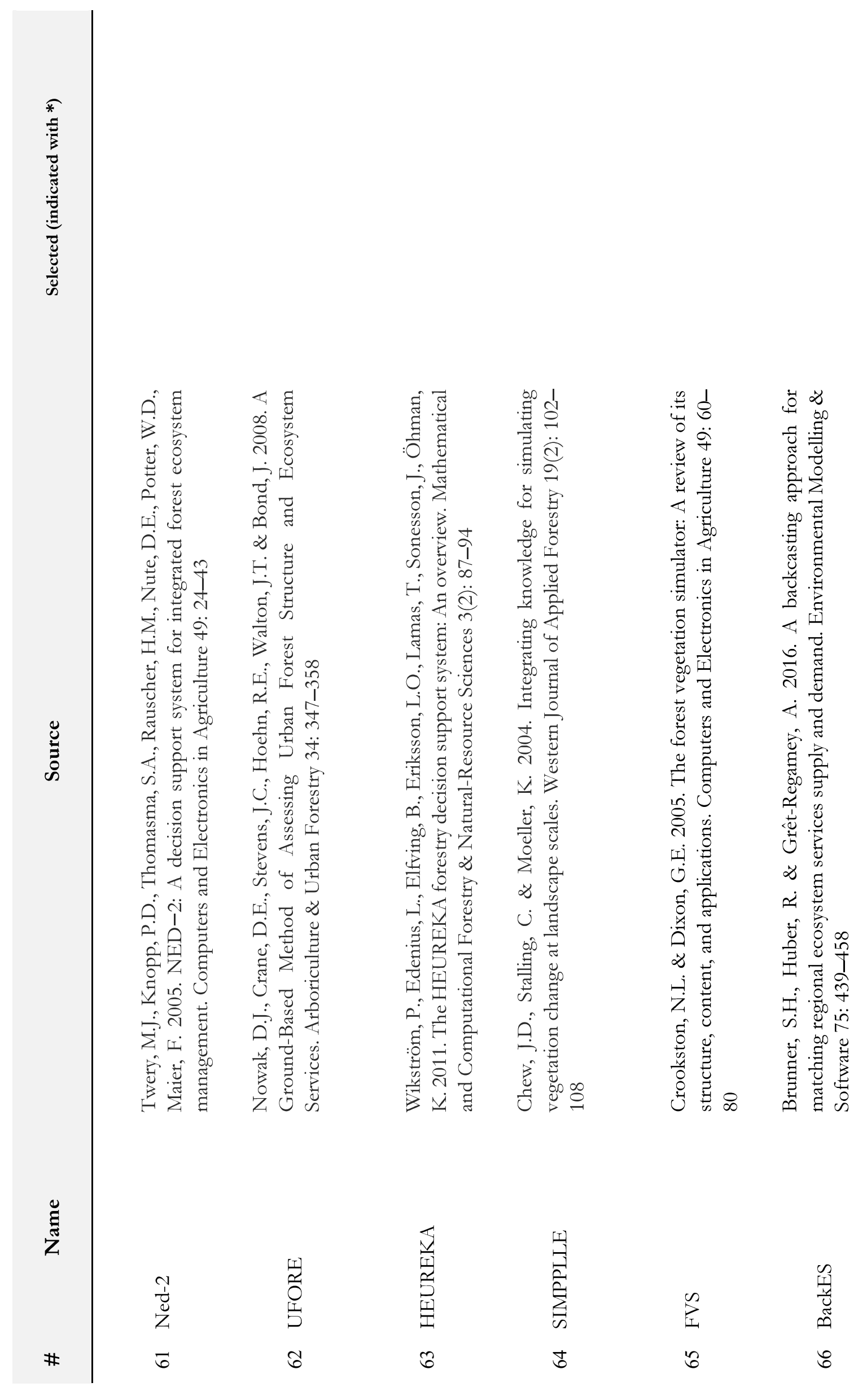




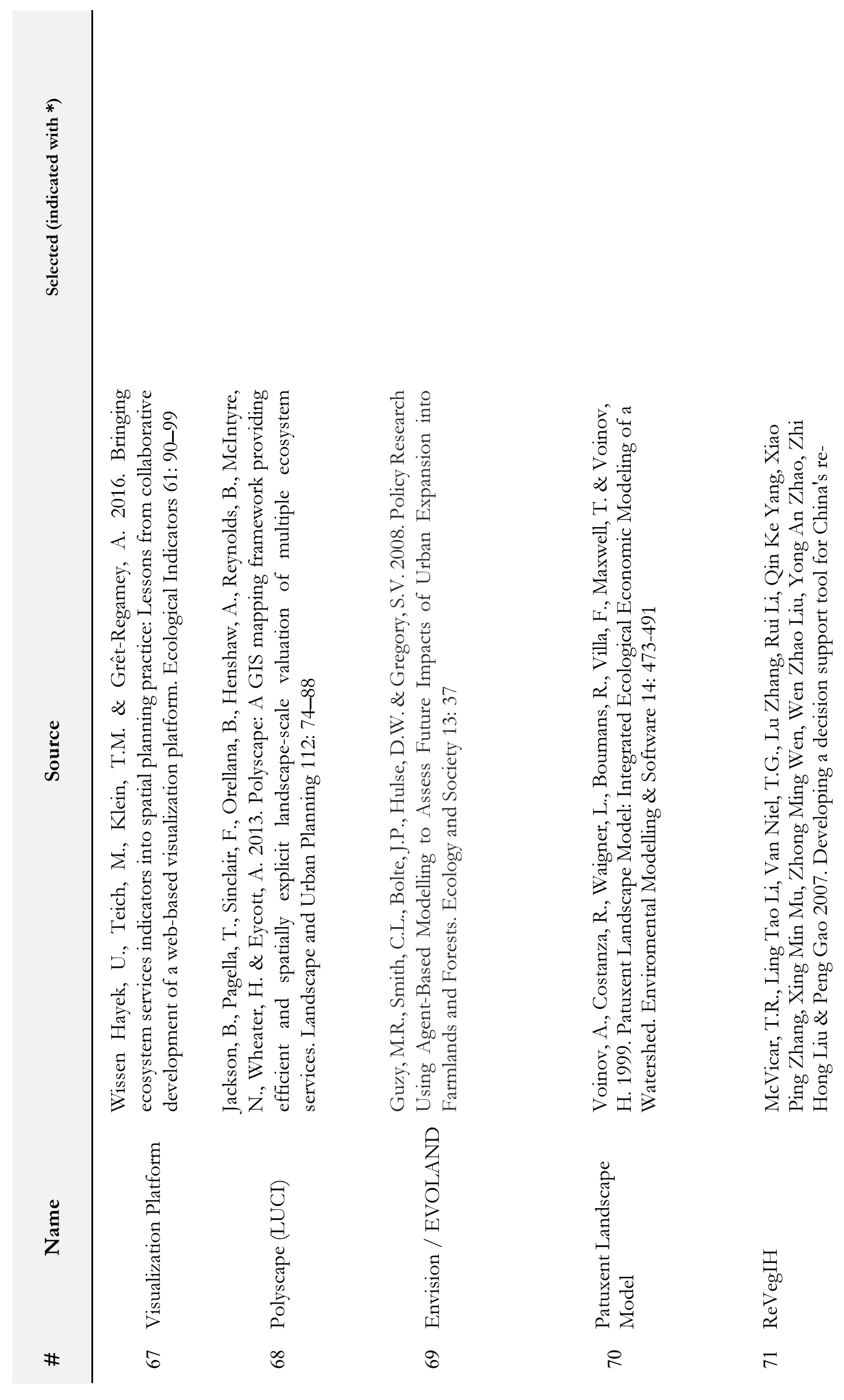



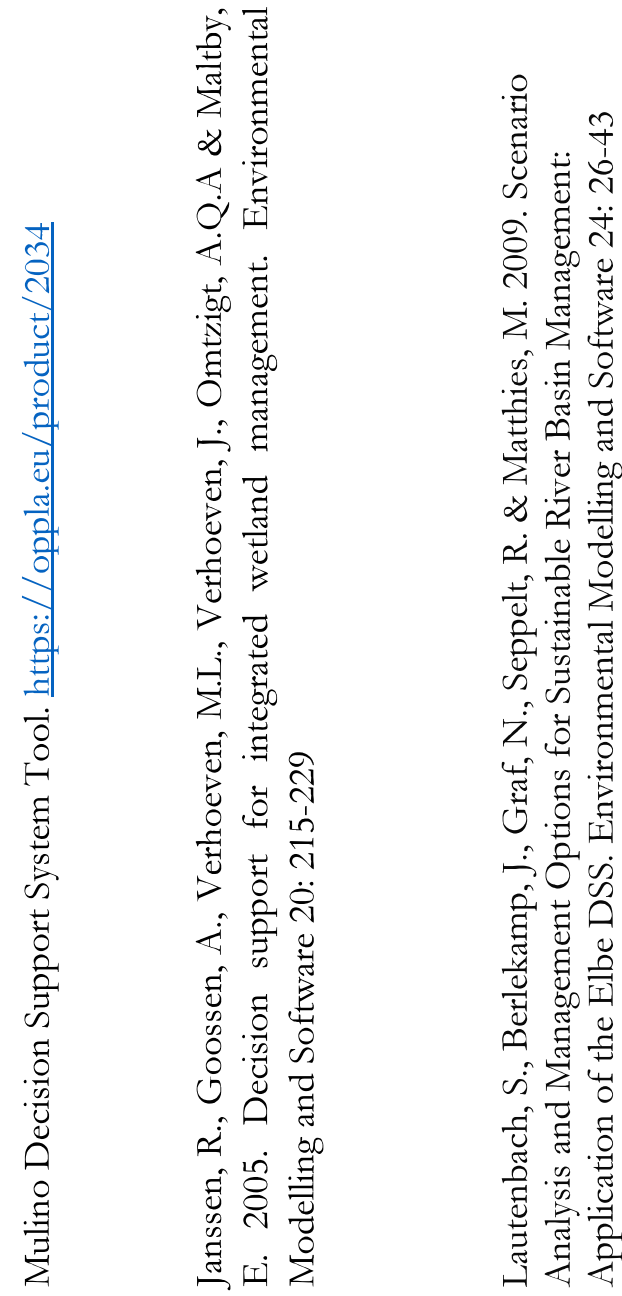

跑节

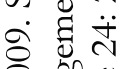

ठำ

玄焉总

包.

焉

羊量

중

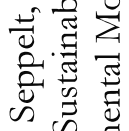

悹焉

之造

矛题言

足

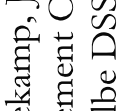

氙 苟

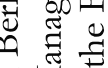

का $\sum^{\pi}$

fु

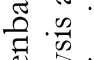

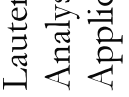

क

동

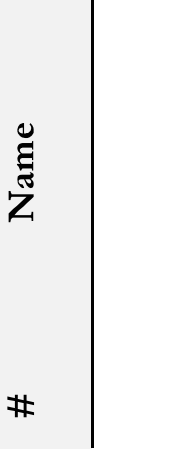




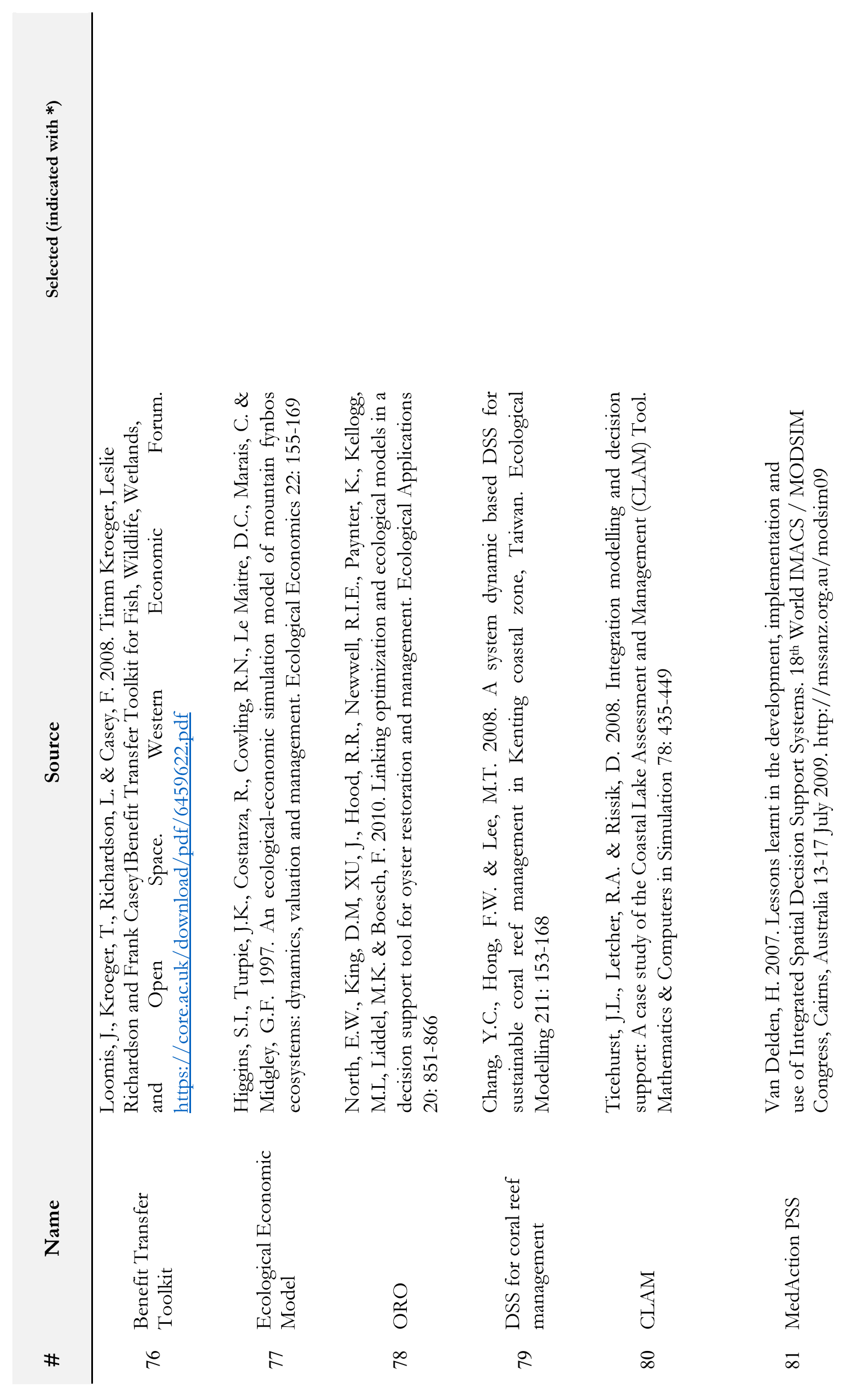

㝏 

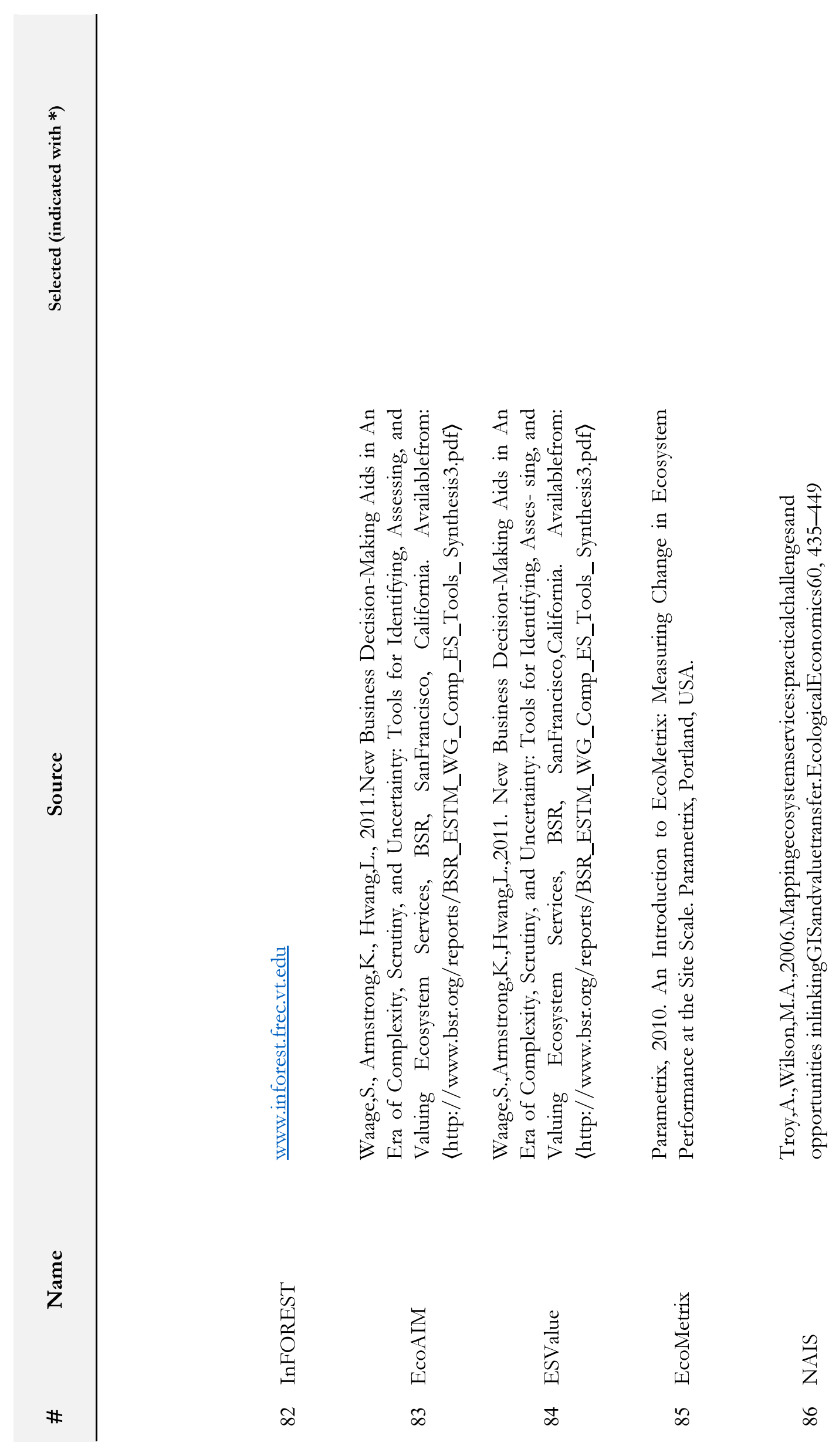


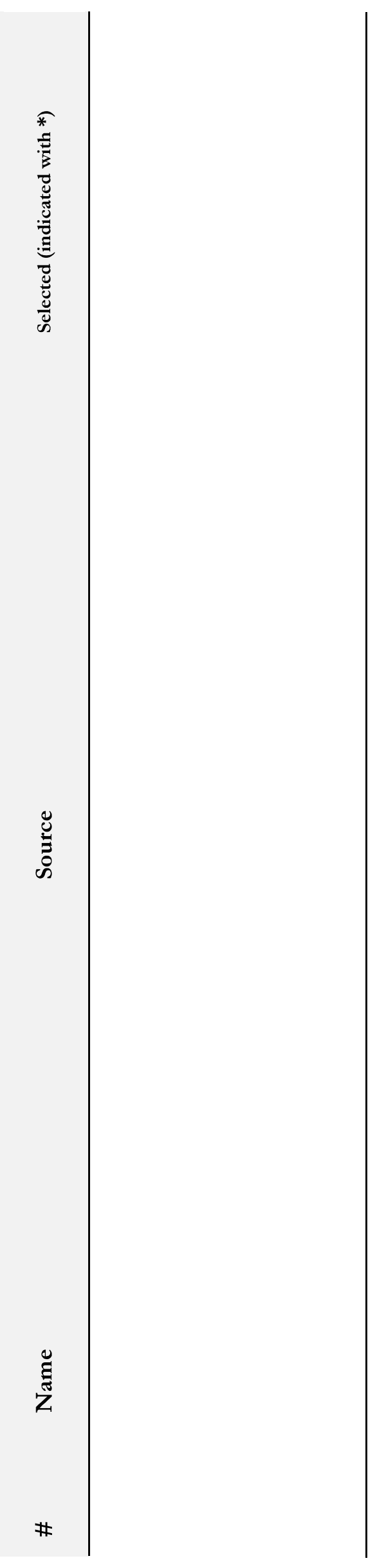


